\title{
THE REFORM OF THE PUBLIC SECTOR AS THE KEY DETERMINANT OF THE TRANSITION ECONOMY OF THE REPUBLIC OF SERBIA
}

\author{
Petar Veselinovic* \\ Faculty of Economics, University of Kragujevac, Kragujevac, Serbia
}

The economy of the Republic of Serbia is at an important turning point now. The first phase of the implementation of the transition process is completed, the reform processes are gaining a new momentum and entering the European Union is becoming more certain. In order to successfully finalize the transition processes, the reform of the public sector's system of functioning is inevitable, among other reforms. The public sector in Serbia is low-productive and inefficient, irrationally set, with a multitude of problems that for many years have constantly been growing and becoming more complicated. The high rate of employment and average salaries in the public sector, on the one hand, and the poorly-formulated operational systems, on the other, are so designed that the public sector has a bad influence on economic development in general. The paper will analyze the situation in the public sector of the Republic of Serbia, with a special emphasis on creating a realistic basis for its reform, as a key determinant of the successful completion of the transition process, taking into account the specifics of the Republic of Serbia's economy.

Keywords: transition, reform of the public sector, business environment, pension system, social protection

JEL Classification: $\mathrm{H} 10, \mathrm{H} 55, \mathrm{H} 60$

\section{INTRODUCTION}

Without the activities that are sponsibility of the public sector, no developed democratic society can be imagined, given that they include the establishment and maintenance of the legal order, the production

\footnotetext{
* Correspodence to: P. Veselinovic, Faculty of Economics, University of Kragujevac, D. Pucara 3, 34000 Kragujevac, Serbia; e-mail: pveselinovic@kg.ac.rs
}

of public goods, public education, public health, the protection of the elderly, the protection of the poor, subsidizing certain industries, the construction of the infrastructure, encouraging scientific research and so on. The efficient functioning of the public sector is an important factor in maintaining macroeconomic stability, economic growth, the standard of living and social welfare. The absence of such features of the functioning of the public sector is a source of serious damage to the functioning of the entire economy. 
The size of the public sector of the Republic of Serbia is not an adequate match to the level of the gross domestic product, and each of its changes, either positive or negative, directly affects the state of the economy. The relation between the public sector and the economic system is a two-way and very causal one. The efficient public sector contributes to the development of the overall economy and vice versa.

The issue of the reform of the public sector has for years been emphasized as one of the imperatives of the successful completion of the transition and the creation of a suitable environment for successful economic development. Rationalization, wage cuts, the public sector reorganization and the restructuring of public enterprises are the essential postulates of the sustainability of the national economy. Nevertheless, the state cannot ignore the social aspect of life for the citizens of the Republic of Serbia, particularly through the health care reform, the pension system and the social security system.

The subject of this paper aims to show the importance of the reform of the public sector as part of the transition process that the Serbian economy is going through. Accordingly, the aim of this paper is to define the key routes or segments of the public sector reform in the Republic of Serbia. Starting from the defined object and the purpose of the research, we will proceed with the testing of the main hypotheses:

If you want a successful completion of the transition of the Serbian economy, it is necessary to implement a comprehensive reform of the public sector.

In accordance with the defined object and purpose of the research, in addition to the usual methodology used in economic research, the method of a comparative analysis will also be used in this paper.

In order to successfully end the transition processes in the Republic of Serbia, changing and optimizing the system of the functioning of the public sector are inevitable. This is one of the essential prerequisites for the economic recovery and a positive trend in the development of the economic system as a whole. To understand the importance of the public sector reform as a key determinant of transition, it is necessary to explain the basic components and characteristics of the public sector. In this paper, the data on the number and the structure of public companies, along with the problems accompanying the public sector, primarily the permanent increase in the public debt caused by fiscal deficits and guarantees that the state provides public enterprises with for the purpose of their borrowing, will be analyzed. Along with the whole analysis, we will also present the specific measures that should lead to the successful reform of the public sector of the Republic of Serbia.

In addition to the introduction and the concluding remarks, this paper consists of three parts. The first part focuses on the basic features of the public sector of the Republic of Serbia; in the second part, the necessity of its reform will be pointed out; and in the third part, an accent will be put on the key segments of the public sector reform: the restructuring of public enterprises, the reform of the pension system, the reform of the health system, and the reform of social protection.

\section{THE BASIC FEATURES OF THE PUBLIC SECTOR OF THE REPUBLIC OF SERBIA}

The reform processes in the Republic of Serbia that have been set in motion are just another example of the fact that good initial results are not sustainable without fundamental changes in the institutional environment of business. In fact, a stable institutional infrastructure that creates a business environment conducive to longterm production growth, employment, investment and exports has not been fully created yet. Such an institutional infrastructure includes clearly designed, long-term and consistent economic system solutions in all areas of business (Veselinović, 2007, 54). The public sector is one of those areas.

The public sector is a part of the national economy, which includes the general government and nonfinancial enterprises controlled by the state (public companies), which are primarily engaged in commercial activities. This sector includes companies engaged in the activities of a common interest to all the citizens: the power utilities, the oil industry, all forms of transportation, postal communications and the 
public utilities. The state or local governments are the founder of these companies.

The public sector of the Republic of Serbia has a long history that dates back to the period of the socialist system of the state and the society. During this period, the public sector represented the "long arm" of the state, and the state used it to directly exert its influence on developments in the national economy.

The public sector of the Republic of Serbia consists of a number of public companies and therefore it can be viewed in the narrower and wider contexts. In the narrower context, the public sector of the Republic of Serbia is made from public companies at the national level of government, public enterprises at the provincial level of government and public enterprises at the local level, while in the broader context, in addition to these public enterprises, the public sector is made from all other companies and individuals thatare both directly and indirectly do business with these public enterprises (Anđelić i Đaković, 2013, 60).

There are no official figures on the number of employees in the public sector of the Republic of Serbia, but all relevant estimates indicate that more than 700,000 workers are directly or indirectly employed in this sector, which is a significant share of the total number of employees $-1,698$ million workers.

The importance of the public sector in the Republic of Serbia can be illustrated by the following data (Arsić $i$ drugi, 2010, 143):

- through taxes and the public spending of more than $40 \%$ of the gross domestic product (GDP) of the Republic of Serbia is redistributed;

- public investments accounted for $15 \%$ of total investment.

The activities and functions of the state and the public sector are commonly called public needs. With his or her own effort, an individual is able to provide housing, food and clothing for him-/herself, or to satisfy part of their personal needs. However, internal and international security, health, education, culture, social security and many other achievements of modern society depend on the existence of an organized activity of the bodies of the state and public institutions.
The main characteristic of the public sector in the Republic of Serbia is its low efficiency and a high level of costs compared to the quality and scope of the services that the sector provides.

The logic of the functioning and organization of the public sector in the Republic of Serbia has not significantly changed over time, although the society has gone through major changes. The question that logically arises is why it did not happen. Why didthe public sector of the Republic of Serbia not go through the changes that were necessary? Why did it not adapt to the change of the social order, social awareness and new market trends? The answer depends on the focus of the analysis. If we set the social consciousness of individuals in the Republic of Serbia as the principal object of an analysis, we could draw the conclusion that the main cause why the public sector has not changedlies in the ambition of the government to keep the situation unchanged, and the public sector can significantly help the government with respect to such an ambition. If we set the economic stability as the principal object of an analysis, then the reason for the public sector not changing might be the authorities' tendency to maintain their positions in the state via alleged economic stability. And, finally, resistance to change within the public sector is also one of the reasons why it is not changing.

In sociological terms, conditions and opportunities in the public sector should follow the situation and circumstances in a country. In the Republic of Serbia, this is not the case. If we analyze the period from the beginning of the 1990s, we can conclude that even in the most difficult periods the Republic of Serbia went through, the situation and circumstances in the public sector, for those employed in it and those collaborating with the sector, were not at all poor compared to those related to the corporate sector, which is privatelyowned. A large number of public companies operated, or continued to operate with losses and, at the same time, the employees of these companies had a position that was significantly above the average of the economy as a whole. Practice shows that public enterprises are the largest businesses with operating losses, and that the same public companies regularly pay high salaries to their employees. 
While trying to define the public sector of the Republic of Serbia, the relation between the number and the structure of public companies between certainlevels of government is interesting to analyze. In the general public, as an example of public enterprises and the public sector in general, enterprises that belong to the national level are usually set. However, if one looks at the structure of the public sector of the Republic of Serbia, one can see that the distribution of the number of public companies in the Republic of Serbia is quite heterogeneous and that a large number of public companies are present at both the local and the national and provincial levels of the government.

The public sector of the Republic of Serbia is too large, and as such, has an adverse effect on the whole of the economy. High costs generated by the public sector represent a serious problem for the budgetary balance, and the level of the budget deficit is one of the most important problems in the economic policy of the Republic of Serbia. The expensive administration of the state directly raises the costs in the economy, thus destimulating current operations, as well as the investment behavior of domestic and foreign companies.

In most public companies, there is little opportunity to determine the optimal level of spending (investment). In such situations, the persons in charge try to spend as much as the approved budget allows, although the predicted amount in the budget may be higher than the objectively required amount. For this reason, many public companies are markedbt as inefficient operational organizations, and the need to change this point of view is justified (Krstić, Stevanović i Džunić, 2011, 434).

The key issues in the public sector of the Republic of Serbia are:

- the high cost of the public administration and the public services in the form of the wage bill of employees and their share in the gross domestic product;

- the common practice of forming a variety of government agencies and similar institutions, without a prior assessment of the existing infrastructure and an analysis of whether the organization performing those jobs or the one having the capacity to perform them already exists in the country or not;

- the irrational spending of the budget funds by subsidizing inefficient public companies;

- the inefficient system of pension insurance, social security, health care, and education;

- the inefficient and bureaucratic administration that encourage the private sector to operate on the grey market.

The inefficiency of public enterprises is a particular problem. The analysis of the financial statements for the period from 2007 to 2011 shows that, except in the first year of the period, the public companies in the Republic of Serbia operated at a net loss in all other years. The biggest amount of the loss was recorded in 2009. In the total net financial result of the economy (the net loss), the share of all the public companies together was about $1 / 4$ (Ministarstvo finansija Republike Srbije, 2011, 19).

The pricing of services in the public sector contains a social component that does not provide economic sustainability, and debt collection mechanisms are inefficient. Management in the majority of these companies is inefficient and under the influence of political parties.

To better understand the necessity of the measures aimed at reforming the public sector of the Republic of Serbia, it is necessary to, first, consider the size of the public sector in the Republic of Serbia and compare it with the data from other countries. Also, it is important to see what the range of the average salary of employees in this sector is.

In the analysis of the public sector, the main question is what size and structure make this sector more efficient. The fact is that there is no single, optimal size of the public sector for all countries, as each country in a given period should evaluate the optimal size of the public sector.

Given the fact that there is no single methodology at the international level which would enable us to compare the size of the public sector by country, we will use the indicator of the participation of the public 
sector employees in the total number of employees in a particular country. For the approximation of the size of the public sector across countries, we have used the data on the number of employees in the sectors of the public administration and defense, compulsory social security, health and social care and education (Ministarstvo finansija Republike Srbije, 2013a, 24).

According to this indicator (Figure 1), the public sector in the Republic of Serbia does not deviate from the public sectors in the selected countries of the European Union. This, of course, does not mean that its size is optimal, and there is still a possibility that there are too many employees in some segments of the public sector, while other segments have a lack of employees.

Figure 1 shows that, considering the number of the public sector employees in 2012, the Republic of Serbia is better than the neighboring countries (Bulgaria, Romania, Czech Republic), but it has fewer employees in the public sector than the certain EU countries Lithuania, Estonia, Latvia, Slovenia, Poland, Hungary and Slovakia.

Another indicator of the size of the public sector, or the share ofpublic expenditure in the GDP (Figure 2), suggests that the size of the public sector of the
Republic of Serbia does not deviate much from the size of the public sectors in other countries. The public sector in the Republic of Serbia spends nearly as much as the public sectors in the Czech Republic and Poland, and a little more than the public sectors in Bulgaria, Romania, Croatia and Turkey.

The displayed data need to be updated with the data on the structure of these expenditures. In the Republic of Serbia, the expenditure on salaries in the public sector and pensions is more than $50 \%$ of the total public expenditure (in 2011, the share was 52.4\%). The amount of public spending on pensions for about 1.6 million pensioners in 2011 was $23 \%$ as high as the amount for the expenses for about 470,000 employees in the public administration and public services. At the same time, the share of capital expenditure in public expenditure was around $8 \%$. It is a means of maintaining the existing public investments and initiating new ones and the amount is less than the expenditure for the purchase of goods and services (for the current government spending), which is about $16 \%$ in the total public spending. The share of compensation for employees in the public sector in the gross domestic product of the Republic of Serbia was at the same level of the participation of these charges in Croatia and

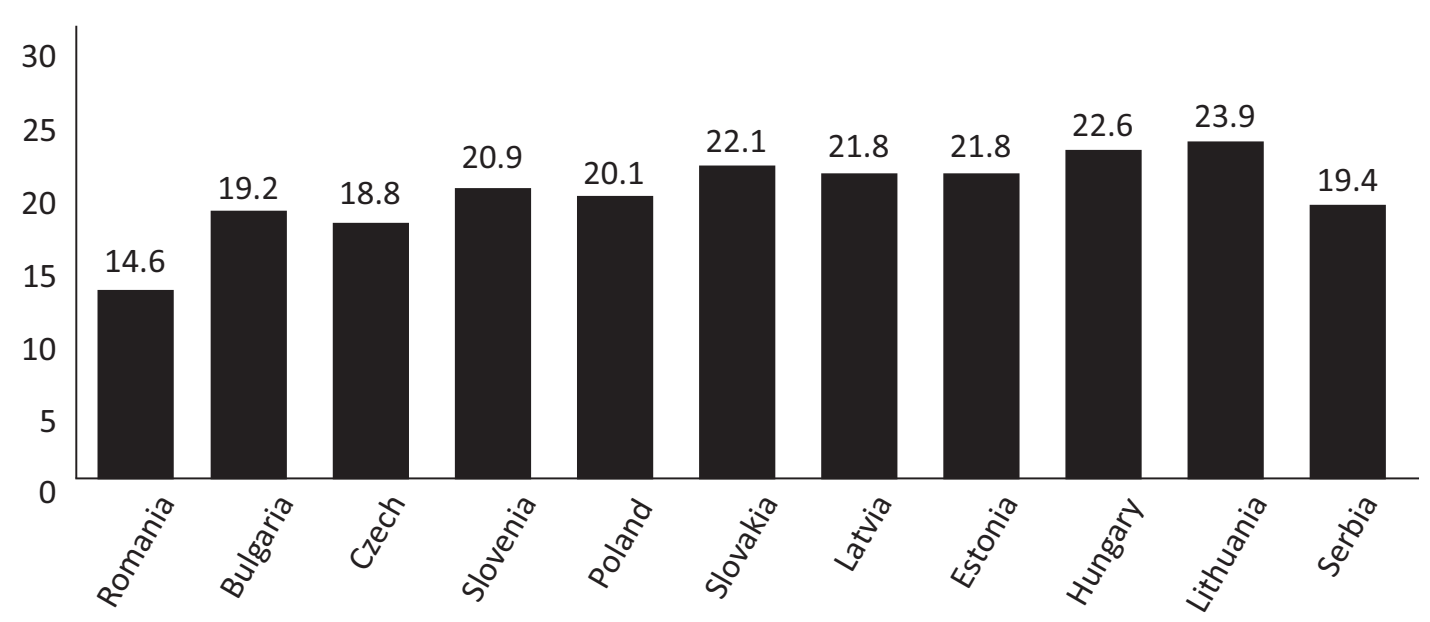

Figure 1 The share of the public sector employment in total employment in 2012 (in \%) 


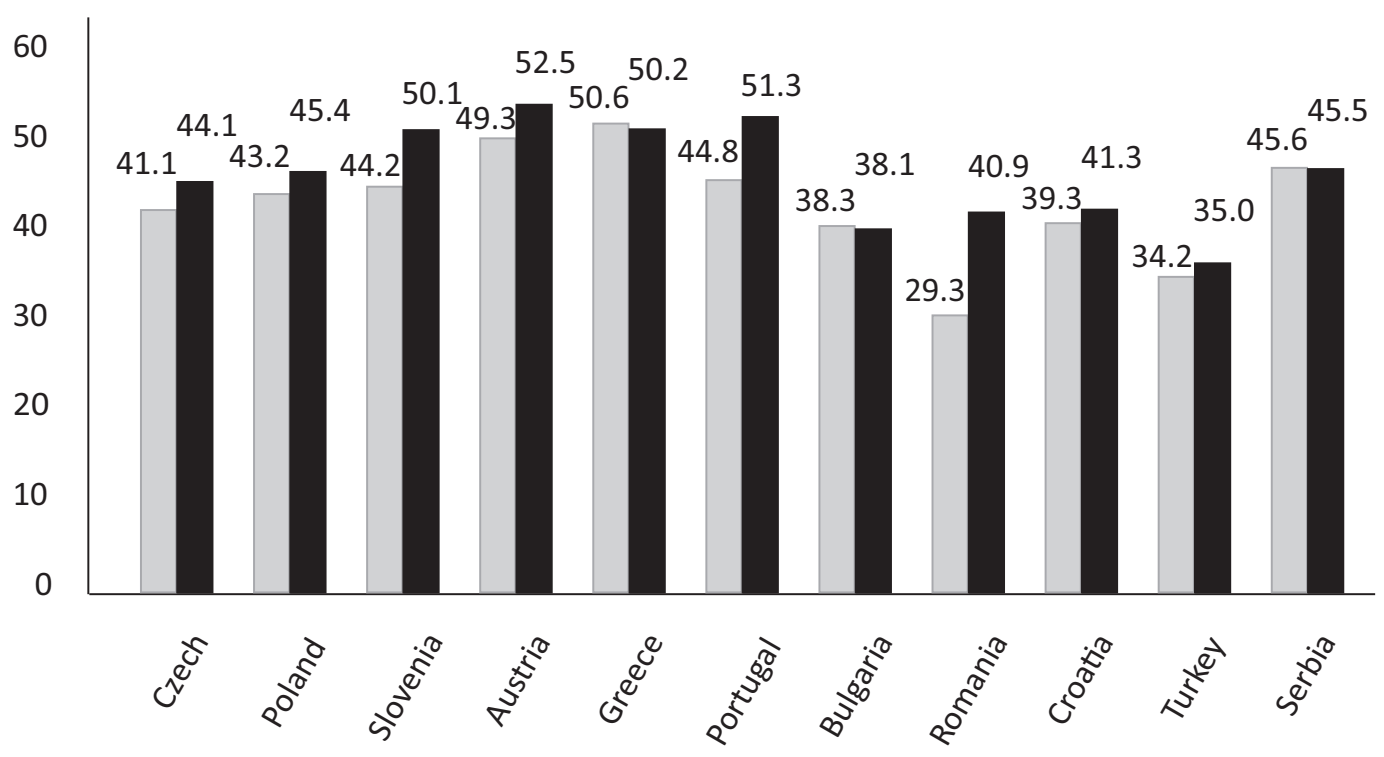

Figure 2 The share of public expenditure in the GDP (in \%)

Source: Author, based on: IMF, 2014, Government Finance Statistics

Poland, but above the level of such participation in Bulgaria, Romania, Austria and the Czech Republic.

Taking into account the transition process in the Republic of Serbia and its impact on the labor market, the relationship between employment in the public sector and the real sector has often been questioned. The transition is known to have affected the decline in the gross domestic product and the growth rate as well as the labor market characterized by high unemployment, a low level of employment in the private sector and a lack of labor mobility (Đuričin, 2011, 234-260). Therefore, numerous works highlight the importance of strengthening the private sector as the driving force of the labor market, with a particular emphasis on the efficient use of the potential of small and medium-sized enterprises.

The average salary in the public sector is higher than the average salary in the Republic of Serbia (Table 1). The average net salary in the Republic of Serbia is only at $70 \%$ of the average net wage in the public sector enterprises, or $78.5 \%$ of the salary in the public administration. As an excuse for higher wages in the public sector versus the private sector, the higher level of the qualification of employees in the public sectoris usually listed. However, there are also significant differences in the level of earnings for the same level of qualifications within the public sector, which makes it necessary to establish a clear principle in the system of wage determination, or the equalization of wages for the same level of qualification.

Table 1 The average net salary in the Republic of Serbia in the private and public sectors (in dinars)

\begin{tabular}{llllll}
\hline & 2009. & 2010. & 2011. & 2012. & 2013. \\
\hline $\begin{array}{l}\text { Average net } \\
\text { salaries (total) }\end{array}$ & 31.733 & 34.142 & 37.976 & 41.377 & 44.182 \\
$\begin{array}{l}\text { Average net } \\
\text { salaries in the } \\
\text { public sector }\end{array}$ & 38.885 & 39.810 & 43.506 & 46.551 & 48.969 \\
$\begin{array}{l}\text { Average net } \\
\text { salaries in the } \\
\text { private sector }\end{array}$ & 24.581 & 28.474 & 32.446 & 36.203 & 39.395 \\
\hline
\end{tabular}

Source: Ministarstvo finansija Republike Srbije, 2013b, 30-33 
Based on the data from Table 1, Figure 3 shows a disproportion of the wages in the private and the public sectors of the Republic of Serbia.

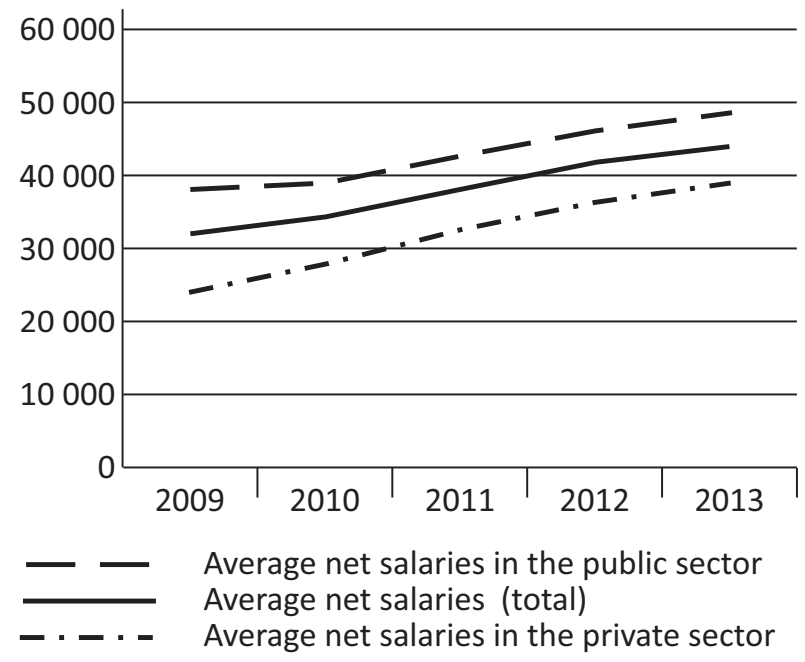

Figure 3 Average net salary in the Republic of Serbia (in dinars)

Source: Author

According to the data of the National Bureau of Statistics, in the period from 2009 to 2013, the wages in the public sector in the Republic of Serbia were 28\% higher than the average one in the private sector, and in some companies they were many times as high: 190\% at "Srbijavode" and Airport "Nikola Tesla”, 180\% at "Telekom", 160\% at "Srbijagas". The average wage in the public sector in July 2013 was 48,969 dinars, while the average salary in the private sector during the same period was only 36,257 dinars. Wages in the public sector compared to the private sector are also high in the neighboring states, but not as high as in the Republic of Serbia: 20\% in Romania, 19\% in Bulgaria, $15 \%$ in Slovakia, and $8 \%$ in Hungary. The Republic of Serbia spends around 13\% of the GDP on the wages in the public sector, which is twice as much as Slovakia or Slovenia spend.

\section{THE NECESSITY OF THE REFORM OF THE PUBLIC SECTOR IN THE REPUBLIC OF SERBIA}

The issue of the public sector reform is one of the fundamental issues of the reform process in the economies of countries in transition. In recent decades, there have been significant changes on the market, in terms of the mode of operation, information, connectivity and effectiveness, all of which have resulted in the need for the redefinition of the role and importance of the public sector in market trends. The public sector reform in transition countries is specific because, in many countries, it either has not started yet or is very slow.

The reform of the public sector of the Republic of Serbia should be seen as a continuous and systematic activity directed towards a clear choice of the public sector that is necessary in the Republic of Serbia. Therefore, before we define the specific directions and measures of the reform of the public sector in the Republic of Serbia, we should first perform a thorough analysis of the current situation in order to obtain a clear and convincing picture of the state of the entire socio-economic system of the Republic of Serbia. This analysis should include, among other things, the following aspects:

- the economic aspect (what the current economic situation of business entities is and how it could be improved);

- the institutional aspect (which laws need to adapt and change in order to successfully implement the reform);

- the social and psychological aspects (what the mood of the population is in terms of their willingness to reform the entire socio-economic system, and the public sector within it).

When we look at these aspects, we can speak about the possible directions of the reform of the public sector of the Republic of Serbia. It is clear that they should be directed towards:

- the corporatization of the public sector,

- more public-private partnerships and 
- a combination of the previous two models.

The corporatization of the public sector of the Republic of Serbia requires a complete redefinition of the institutional public sector in terms of creating public companies, which would consequently lead to the redefinition of organizational and management approaches in these companies. The advantages of this approach are reflected in the fact that the operations of the public sector would to a greater extent adapt to the market needs, where as one of the main drawbacks lies in a potential danger of changing the ownership structure and the impact of private equity on its functioning. This circumstance could create some challenges since the interest of private investors and the state is known to often be different from each other (investors are primarily guided by the motive of profit maximization, and the state also has to take care of the social and other needs, which is a natural thing to do). However, this model could contribute to increasing productivity and efficiency in the public sector because responsibility in business could clearly be determined. If, along with the implementation of this model, the total professionalization of the public sector would be insisted on, this model could provide satisfactory results.

A public-private partnership is the model which has been the subject of many debates and theories for a long time. Developed countries' experiences support the idea that this model has greatly been optimized for certain activities that are now covered by the public sector. There is, however, a logical question of the possibilities of the practical implementation of this model in the Republic of Serbia.

A public-private partnership is a long-term contractual partnership between the public and the private sectors, which may include: the design, financing, construction, management or provision of services by the private sector, which are traditionally provided by the public sector. In fact, it is the model that brings benefits to both sides and includes the successful combination of the objectives of the public and the private sectors. A public-private partnership is a common corporate operation of the public and the private sectors aimed at a more economical, more efficient and successful production of public goods or services compared to the traditional way of providing services. In this case, the public sector is a partner that, in the contract, defines the type and scope of work or services he or she intends to transfer to the private sector. The private sector emerges as a partner that requires such cooperation if a profit can be made, and is required to properly execute the tasks defined in the contract (Dimitrijević i Cvetković, 2010, 121-130).

The result of combining the previous two models would be considerable flexibility and a possibility of adapting the offered solutions, with full consideration of the particularities of the public sector of the Republic of Serbia at the national, provincial and local levels. On the other hand, there is a real danger that this combined approach could prove to be inapplicable because the socio-economic system of the Republic of Serbia is still not ready for such an arrangement of the public sector. It seems that a combination of the previous two models would be the optimal solution for the Republic of Serbia, which, however, cannot be claimed with certainty as long as it hasperformed the necessary analysis and an assessment of the situation and the opportunities in the Serbian market, with a projection of expected trends.

The public sector reform has been an inexhaustible topic in recent years. The perennial politicization of the public sector, the irrational economic, personnel and general business policies, the lack of the understanding of the position of the public sector in modern society and the unwillingness on the state's part to rationally start its reform are just some of the reasons for the low productivity of and the undercapitalized public sector. The global financial crisis has further aggravated the situation in the region, and the reaction of the economic policy was an inadequate one. The reaction of the fiscal and monetary policy was uncoordinated, mainly extracted, and almost like there was no crisis at all. Under the pressure from the political elite, the fiscal policy met part of the populist campaign promises, and increased public spending despite the crisis (Petrović, 2009, 43).

All of the above-mentioned shows that it is necessary that the legacy of the previous period should be cleared up, and, following the example of the countries that have the well-appointed public sectors, that the 
reforming of the public sector of the Republic of Serbia should be started. A stable public sector is well-known to be the basis of the development of the country and the foundation supporting its long-term economic progress, while an unstable public sector slows down the development of the country.

\section{THE KEY SEGMENTS OF THE SERBIAN PUBLIC SECTOR REFORM}

According to the above analysis, we can see that the reform of the public sector of the Republic of Serbia is a very complex process which should include: the restructuring of public enterprises, the pension reform, the health care reform and the reform of the social protection systems.

The scientific and professional community differently defines the term "public company", which rightfully raises the question of what is public and why it is public. The Law on Public Enterprises defines the notion of a public company as a public company performing the activities of a general interest, established by the state or the local government or the autonomous province. However, the Law on Public Enterprises shows that the activities of a general interest may be performed by other companies and other entrepreneurs.

According to the legislation of the Republic of Serbia, public companies can operate with the state-owned and private resources and resources of other forms of ownershi These are companies doing business in the public interest. The subject of their activities is products called public goods and public services. A public good is any good produced in the field of a public economy. It is characterized by non-rivalry and non-excludability. Non-rivalry means that, at any stage of a commercial use, it is impossible to exclude any other individual consumer from consumption. Nonexcludability means that a good intended for a certain individual or group can be used by other people, at little or no additional costs.

In the Republic of Serbia, there are 715 public and public utility companies that are listed at the National Bank of Serbia. In the Business Registers Agency, 703 companies are registered as active (five are in the registration process, five in bankruptcy and two in liquidation proceedings). Companies such as "Srbijagas”, „Železnice Srbije”, „Putevi Srbije”, „Elektroprivreda Srbije”, „Pošta Srbije”, „Elektromreže Srbije”, Belgrade „Nikola Tesla” Airport, „Telekom Srbija”, „Srbijašume”, „Srbijavode”, „Vojvodina šume” and similar ones, employ a significant number of people, have a great asset and are vital to the entire economic system of the Republic of Serbia.

The realized losses reported in the annual accounts of most public companies indicate that they are in a worrying situation. Their inadequate management and their long-standing effort to balance between the social and the market ways of doing business have led such companies to a precarious financial situation.

The biggest problems faced by public companies in the Republic of Serbia are as follows:

- a great political influence in the election of the members of the management and the supervisory boards, which results in weak corporate governance and poor business results;

- losses have been accumulated for years, hampering the investment and development opportunities of this type of companies;

- the very low effectiveness and efficiency of the management, which is reflected in the quality and range of products and services of these companies;

- financial imbalances - public enterprises operate as illiquid and have high rates of indebtedness, which is mostly the consequence of a lack of the capacity of this sector of the company in the area of financial management;

- great opportunities for corruption and

- redundancy and the inadequate qualification and age structure of employees.

Many problems arise in public enterprises at the local level, and they are reflected in: technical and technological obsolescence, the oversize of many of these enterprises, propensity for irrational consumption while there is high indebtedness, a loss and a high budgetary dependence, as well as 
an inability to finance participation in large-scale investments with their own resources.

Since the beginning of the transition in the Republic of Serbia, there has been no attempt to implement areal process of the restructuring of public enterprises. In the period after 2000, most changes were aimed at changing the organizational structure and staff reductions. Despite the measures taken, public companies in Serbia still do not produce results commensurate with their importance, expectations and great business potential.

It is important to note that, in the professional community, there are still conflicting opinions about privatization, which just highlights the importance of the process of the restructuring of public enterprises, prior to privatization. Thus, the conclusion is that, regardless of whether public enterprises will be privatized or not, the continuation of such restructuring is necessary in order to improve their efficiency.

Two main groups of factors affecting the process of the restructuring of public enterprises in the Republic of Serbia can be categorized into external and internal factors (Mihajlović, Mihić i Rađenović, 2013, 157-176).

External factors are closely related to anappropriate institutional environment. The generator of this environment is certainly the government of a country. It is an institutional environment that has been lacking the most throughout the transition period, in order to generate changes in the business environment, because companies operating in the conditions of developed markets feel the inner need but are also forced to go through various restructuring activities. This is necessary to ensure the survival, growth and development.

Internal factors simply "push" companies to go through changes and restructuring. Internal factors are reflected in the owner's pressure on the managers to bring the company to createa high level of well-being. One gets an impression that, in public enterprises in the Republic of Serbia, it is not clearly defined who is the one to set goals, lead the company towards the achievement of the goals set and exercise control.
Without clearly defined ownership relations, there is a lack of a very important internal momentum for the restructuring of public enterprises to make changes in order to create and strengthen their financial situation.

The current situation that public companies are in requires an urgent initiation of the restructuring process that cannot be universal and applied equally to all. This process needs to be continuously implemented in each company, taking into account their specifics. The restructuring process will vary from one company to another, and in most companies, it implies cutting the number of employees and improving governance.

Improving the management of public enterprises should contribute to increasing their efficiency by reducing unnecessary waste of resources, increasing the volume and improving the quality of services, upgrading technology etc. Increasing the efficiency of public enterprises is of great importance for the economy and the citizens, not only because of the great value of the services they deliver but also because of a large part of social wealth being under their control.

A significant segment of the reforms of the public sector of the Republic of Serbia refers to the reform of the pension system.

The public pension system of the Republic of Serbia is based on the principle of inter-generational solidarity - active workers pay pension contributions which are used to payout current retirees.

Pension insurance is divided into three pillars:

- the first pillar is mandatory state pension insurance. It works on the principle of current financing, where contributions paid into the Pension Fund on behalf of the employer and employeesare immediately paid out in the form of pensions to current retirees;

- the second pillar is mandatory supplementary private pension insurance, in which a portion of mandatory contributions that would go into the state pension fund is directed to the compulsory private pension fund, so that the employee may be entitled to two pensions - the private and the state ones; 
- the third pillar is voluntary pension insurance, which gives an opportunity to all, regardless of whether they are employed or not, to allocate additional pension contributions to private accounts and ensure additional benefits in the future.

The Republic Fund for Pension and Disability Insurance is established under the Law on Pension and Disability Insurance to ensure the exercise of rights from pension and disability insurance and to provide funds for the realization of these rights (Raičević, $2008,304)$. The Fund is a legal entity with the status of anorganization for mandatory social insurance, with the rights and obligations established by the law and the statute. The Fund provides the right to pension and disability insurance to all persons who are insured by law and who are included in this insurance, regardless of whether they are employees, self-employed or farmers.

Faced with new structural socio-economic and demographic changes, such as a tendency to increase life expectancy, unemployment and the negative effects of high pension insurance contributions on employees' paid-outwages, policy makers have a great limitation in increasing public spending on behalf of pension payments. The increase in pension expenditure has become the main burden of public finances in the Republic of Serbia in recent decades. Therefore, an increase in the pension expense requires the reforming of pension insurance in order to increase the contribution rates, the changes of the accounting period for determining the pension right and the mechanism of adjusting the amount as well as the reduced pension rights.

Public expenditure on pensions is based on demographic and macroeconomic values. The birth rate, life expectancy and migration flows, macroeconomic trends, the pace of the gross domestic product, wages, reduction of the employment rates and social factors (early retirement, claims for disability pensions) are the most important elements determining the movement of the state pension insurance funds. The level of public expenditure on pensions is certainly affected by change of legislation (the mechanism of the adjustment of pensions to the current economic conditions or the indexation mechanism, the regulated conditions for retirement etc.) (Hrustić i Dimitrijević, 2009, 89-101).

The Table 2 data show that the number of insured persons comparing to the number of beneficiaries decreased from one year to another. This merely shows how real a possibility of the sustainability of the pension system were if the trend of increasing the number of retirees relative to the number of employees continued.

Table 2 Developments of the number of retirees and the number of insured persons in the category of employees in the Republic of Serbia

\begin{tabular}{|c|c|c|c|}
\hline Year & $\begin{array}{l}\text { Number of } \\
\text { retirees }\end{array}$ & $\begin{array}{c}\text { Number } \\
\text { of insured } \\
\text { people }\end{array}$ & Ratio \\
\hline & 1 & 2 & $1: 2$ \\
\hline 1999 & 1.263 .315 & 1.992 .181 & $1: 1,5$ \\
\hline 2000 & 1.264 .175 & 1.927 .588 & $1: 1,5$ \\
\hline 2001 & 1.297 .004 & 1.919 .255 & $1: 1,5$ \\
\hline 2002 & 1.255 .814 & 1.876 .390 & $1: 1,5$ \\
\hline 2003 & 1.248 .662 & 1.841 .219 & $1: 1,5$ \\
\hline 2004 & 1.241 .082 & 1.841 .656 & $1: 1,5$ \\
\hline 2005 & 1.239 .573 & 1.839 .461 & $1: 1,5$ \\
\hline 2006 & 1.267 .574 & 1.792 .497 & $1: 1,4$ \\
\hline 2007 & 1.290 .611 & 1.760 .437 & $1: 1,4$ \\
\hline 2008 & 1.306 .394 & 1.772 .418 & $1: 1,4$ \\
\hline 2009 & 1.324 .338 & 1.678 .760 & $1: 1,3$ \\
\hline 2010 & 1.345 .733 & 1.605 .052 & $1: 1,2$ \\
\hline 2011 & 1.357 .846 & 1.542 .282 & $1: 1,1$ \\
\hline 2012 & 1.420 .892 & 1.518 .792 & $1: 1,1$ \\
\hline
\end{tabular}

Source: Republic Agency for Pension and Disability Insurance, 2012

For the optimal functioning and liquidity of the pension system, it is better that there are more employees perone retiree. It is very important to note that this relationship is significantly influenced 
by the fact that, in the Republic of Serbia, there is a strong tendency of the aging of the population, thus increasing the number of retirees from one year to another. Also, as unemployment grows from one year to another, and as many young people cannot find work, this ratio will continue to move unfavorably because of the downsized number of employees comparing to the number of retirees. That is why creating new jobs is believed to be an indirect factor that can affect the improvement of this relationship in the future, reducing unemployment in that way. However, there is another factor that may affect the favorable trend of this relationship, and that factor is lifting the age limits for retirement.

Although the pension system reforms were repeatedly being implemented during the period from 2002 to 2010, the Republic of Serbia remains in the group of countries with the questionable sustainability of the public pension system. Pension expenditures are 13\% of the GDP, which is $4.5 \%$ more than the average in the European transition countries, which is a burden on the economy and taxpayers that they cannot withstand in the long run.

One of the causes of the unsustainable pension system is the fact that the current reform measures have not sanctioned retiring before the regular retirement age, so that about $70 \%$ of men retire before the age of 65 and about $50 \%$ of women retire before the age of 60 (Figure $4)$.

In the European Union, there is a continuing trend of lifting the age limits for retirement; so in the UK, men retire at 65 and women at 60; in Portugal, women retire at 62 and men at 65 . In Greece, the standard age limit for pension has increased to 65 years for both men and women.

Bearing in mind the above analysis, it is very important to impose the following measures of the reform of the pension system of the Republic of Serbia:

- The introduction of actuarial factors or penalties for early retirement and rewards for late retirement. This measure would allow the pension system to be financially neutral towards the insured (the same generation) who retire at different ages. In practice, this would mean that the insured who retired earlier/later would receive a proportionately reduced/increased pension, in order to achieve a financial equivalence between insured persons who retire at different ages.

- The gradual equalization of the age limit for retirement for men and women to 65 years of age. This measure has been a subject of debate for years, not only in the domestic literature but also in the foreign one as well. It effectively allows you to

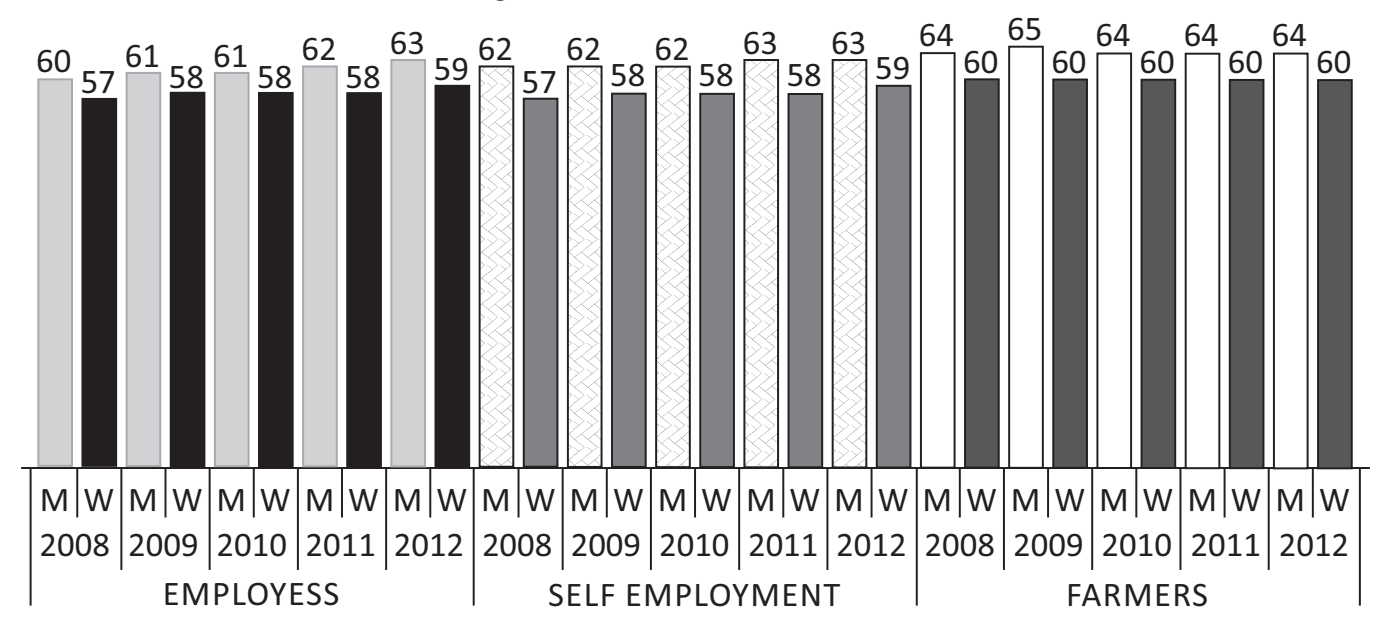

Figure 4 The average age of retirees in the Republic of Serbia in the period from 2008 to 2012 
extend the length of service of employees, and thus extend the period of the payment of contributions into the Pension Fund. The prolonging of life expectancy should particularly be taken into account at this point because it further affects the raising of the age limit for retirement. In fact, as life expectancy increases, the age limit for retirement should also increase. Because if that didnot happen, the ratio between the number of employees and retirees would be more and more unfavorable, which would have a negative impact on the liquidity of the Pension Fund. Figure 5 shows the age limit for retirement after the reforms implemented in 2012.

- Increasing the age of retirement for both sexes, according to the increasing life expectancy of the population. Policy makers in the Republic of Serbia have increasingly been emphasizing a possibility of legally increasingthe age limit for retirement to 65 years for both men and women. However, a certain level of carefulness has to be employed with the implementation of this measure, because if gaps in the financial balance still existed after implementing all these measures, the last step would be to consider an increase in the contribution rate. This is the most rigorous measure that could adversely affect the standard of the current employees, if there were not a proportionate increase in their salaries.

- The introduction of a reduction of the pension contribution for retired persons who work. Taking into account the results of the previous reforms of the pension system and the need to adapt to demographic changes, the long-standing problem of the insolvency of the pension fund should be dealt with at a higher pace of the economic activity that would primarily be directed towards the growth of the gross domestic product and employment. In addition, it is necessary that the pension system itself should be reformed, as defined pension benefits relate to the lump sum payments of a part of the contribution, not the present value of an annuity (Clark, Sandler Morrill \& Vanderweide, 2014, 73).

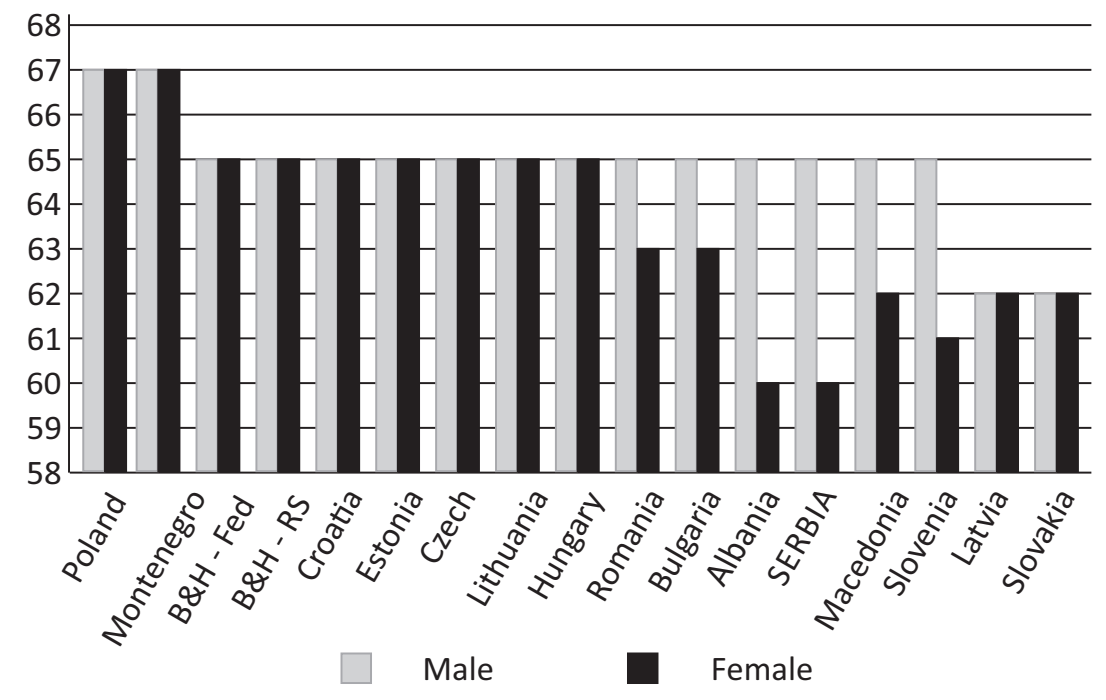

Figure 5 The average age of retirees in the Republic of Serbia and other countries following the reform in 2012 
The reform of pension insurance requires a change inthe calculation period for determining the amount of the pension; then, changing the indexation, tightening the eligibility conditions - the most important being an increase in the standard age limit for retirement. On the other hand, we must not forget that the quality of life and the level of the purchasing power of pensioners are also a social category, and the scope for further reducing the amount of pension is extremely narrow according to the current economic indicators in general. Especially in the context of the global financial crisis, the amount of pension is a segment that should certainly be protected by measures of mitigating the effects of the crisis.

To stimulate the economic recovery and to create conditions for economic growth should certainly be a priority in solving the problem of the illiquidity of the pension insurance system in the Republic of Serbia. However, economic policies should stimulate increased production and employment, thereby increasing the number of taxpayers and the volume of collected revenues from pension contributions at the same time.

A significant segment of the public sector reform in the Republic of Serbia also refers to the reform of the health care system.

Public expenditures on health care in the world have been well-known to be one of the fastest-growing elements of public expenditure over the past few decades. Empirical studies show that technical progress in medicine, increasing access to health care for a large part of the population, and the aging of the population, all have the greatest impact on the cost of health care in relation to the gross domestic product.

According to the World Health Organization, public expenditure on health care in the Republic of Serbia accounts for about $70 \%$ of the total expenditure on health (Arsić i drugi, 2010, 166). If we look at Figure 6 including data up to 2011, we will see that the share of the total health care expenditures in the gross

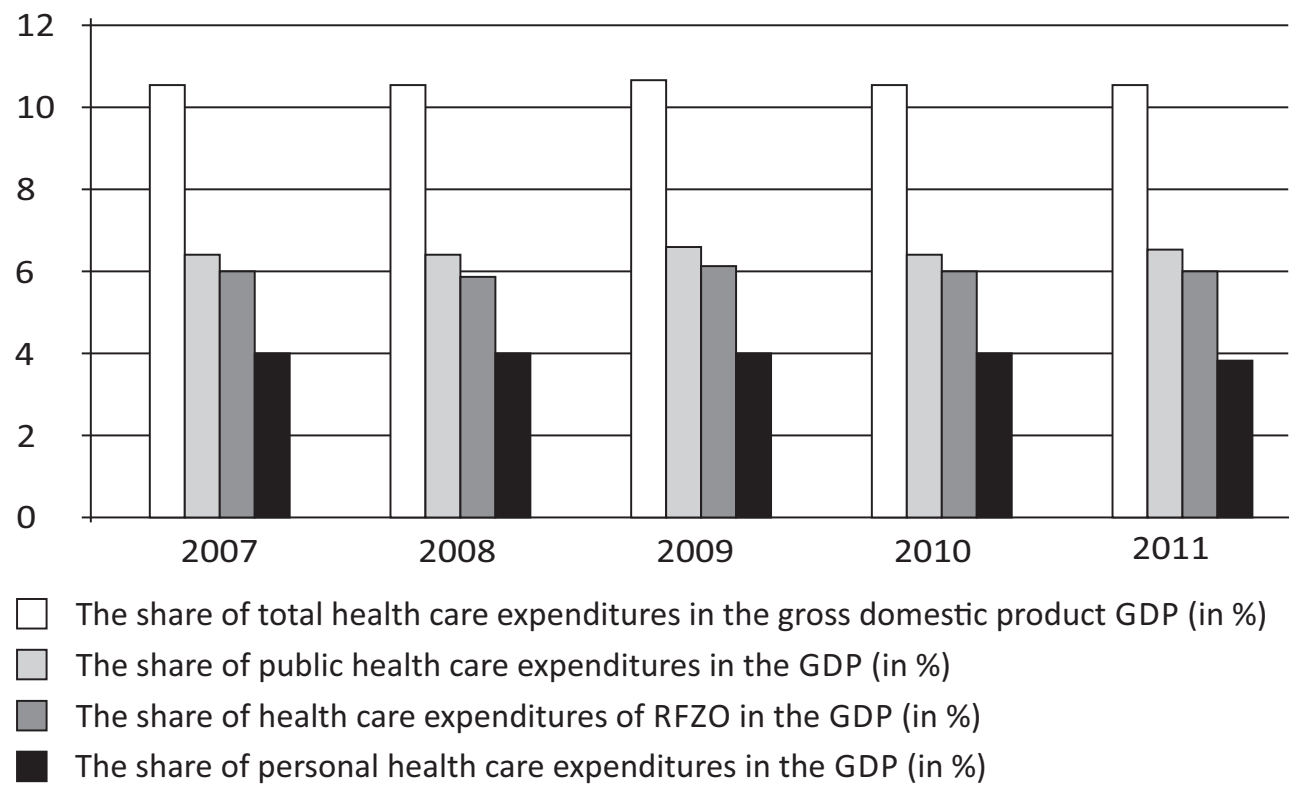

Figure 6 Funding by the source of the international classification of health care expressed as a percentage of the gross domestic product (GDP)

Source: Author, based on: Institut za javno zdravlje Srbije, 2011 
domestic product of the Republic of Serbia increased by one percentage point in 2008 in comparison with the previous year, and stabilized at $10.4 \%$ in the following years, with a slight increase to $10.5 \%$ in 2009 . The share of private expenditures on health care stabilized at $4 \%$ of the gross domestic product after an increase of half a percentage in 2008. The share of the public expenditure on health care of the Health Insurance in the gross domestic product was approximately $6 \%$ during the monitored period; in 2007, however, it increased by half percent, slightly fluctuating over the next two years. The share of public expenditure on health care in the GDP was $6.4 \%$ on average during the entire period.

Looking at spending on health care as a percentage of the gross domestic product, the Republic of Serbia, with its $10.4 \%$, is close to the level of Belgium, Austria, Greece and Bosnia and Herzegovina, and is at a much higher level than numerous countries: Albania, Bulgaria, Croatia, the Czech Republic, Estonia,
Finland, Hungary, Latvia, Lithuania, Luxembourg, Montenegro, Poland, Romania, Russia, Slovakia, Macedonia and Turkey.

However, Figure 7 shows that, compared with the European Union and other European countries, the Republic of Serbia assigns a small absolute amount of funds for health careas a result of the relatively low level of the gross domestic product.

Given the fact that, relative to the gross domestic product, public expenditures on health care in the Republic of Serbia are higher than in comparable countries in transition, and that the results of health care are average, it can be said that there are significant inefficiencies in the health system. It certainly raises the need for a fundamental reform of the health system, which would result in improving the efficiency of health care.

As recommended by the World Bank, the most important savings in the public health system of the

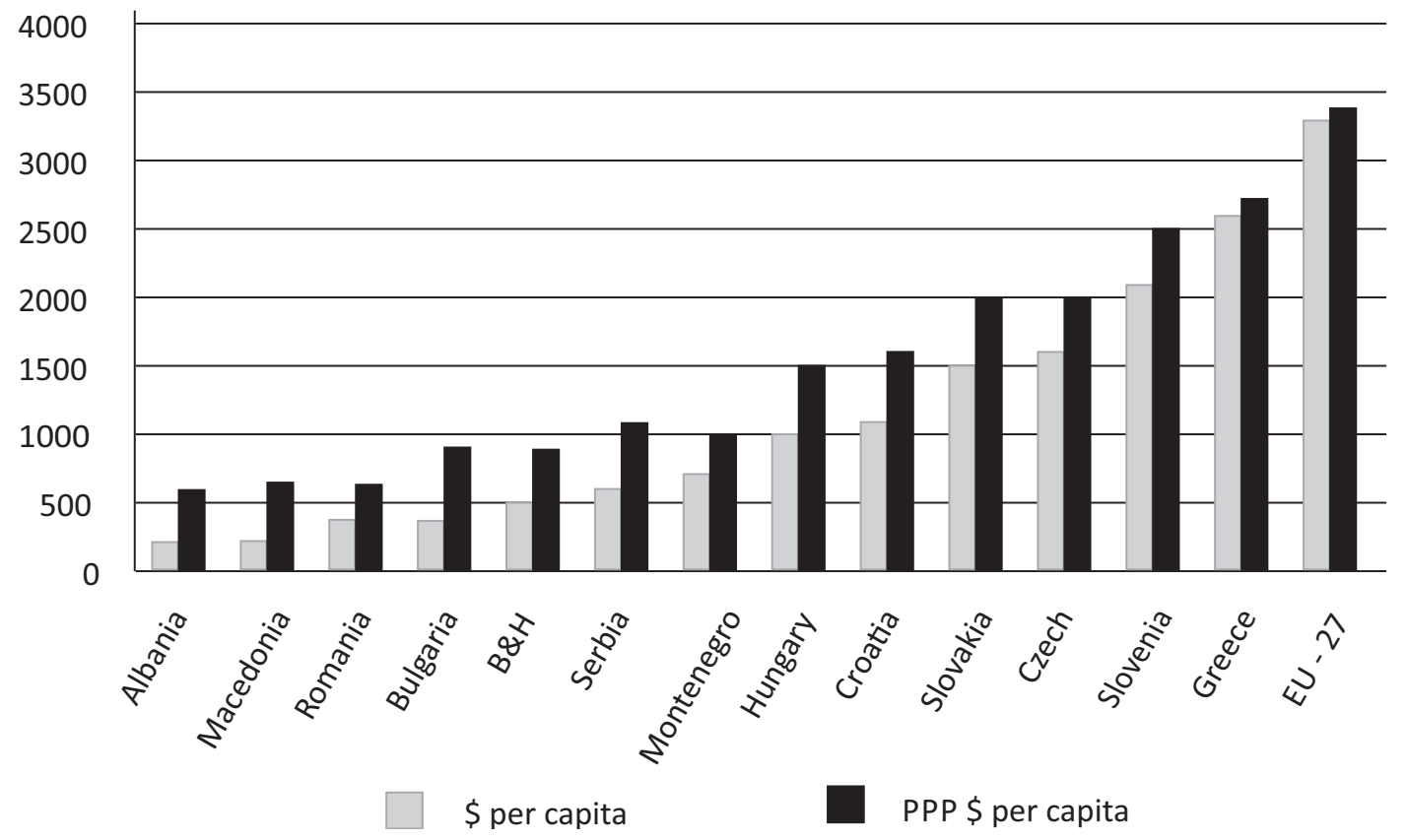

Figure 7 The total expenditure on health care (in U. S. dollars per capita and in U.S. dollars at purchasing power per capita) in theRepublic of Serbia, EU-27 and the selected European countries

Source: Author, based on: Institut za javno zdravlje Srbije, 2012 
Republic of Serbia are primarily related to the reduction in the number of non-medical staff in the areas of public health and the improvement of the decision procedures for the purchase of new technology and the approval of new drugs in the so-called positive list. A possible route could also be the computerization of the entire system of the administration of the services provided by health care facilities and the introduction of electronic charts. Namely, because the medical history of patients is still being recorded in a traditional manner, the overall system is functioning inefficiently, and is overloaded with a huge number of charts, and the patient data is often lost. An electronic database would help solve these problems and would provide easier and faster access to information about patients.

The realization of these reforms requires high vigilance in order not to repeat the mistakes that were made in the past. The reduction in the number of health care employees based on the voluntary departure of employees, with a relatively high severance, has resulted in the health care system being left without some of the most needed medical staff who switched to the private sector. At the same time, the number of non-medical staff, who were in a surplus, remained unchanged, which jeopardized the functionality of the health system.

The rationalization of the number of employees in the health system of the Republic of Serbia has to take into account the existence of significant disparities in the productivity of health care institutions. In fact, more than half of health centers have the capacity utilization of less than two-thirds, on the one hand, whereas, on the other, there are health centers that are overloaded. Such capacity utilization in health care institutions is partly the consequence of the fact that the demographics of the Republic of Serbia, from the territorial aspect, have significantly changed in the last twenty years.

According to the recommendation of the World Bank, a change of funding the public care system in the Republic of Serbia could contribute to the increasing efficiency of health care institutions. The current health care system is financed on a cost basis, health institutions receive funds from the Health Insurance
Fund based on the number and structure of employees, the cost of drugs and the number of beds. The key reform steps in this sector will involve a completely different model of funding, so health care will be financed by the users of health services. By using this model, health centers which have a larger number of patients would receive more funds. The savings in the health system that would be achieved by applying these measures would be used to purchase modern medical equipment, improve the qualification of medical personnel and reconstruct health facilities. Furthermore, significant resources could be diverted to the social welfare system.

In the Republic of Serbia, there are over twenty social assistance programs. The goals of these programs can be classified into three groups, namely:

- poverty reduction,

- population growth, and

- assistance to vulnerable groups (veterans and the disabled).

According to the official figures, expenditure on social protection in the Republic of Serbia is significantly lower than it is the case in most other countries in transition. The total expenditure on social protection is less than $2 \%$ of the gross domestic product, while these expenses in Central Europe range between 3 and $4 \%$. However, if the various forms of the state aid are included, the actual expenditure on social protection in Republic of Serbia is likely to be somewhat higher because the Republic of Serbia is, in different ways, still shifting certain social functions to companies, so the poorer sections of the population receive discounts for paying utilities etc. (Arsić i drugi, 2010, 172).

Another drawback in the system of social protection is that a relatively small part of the social assistance programs are directly aimed at solving the problem of poverty. The relatively modest funds in the Republic of Serbia for the poor are insufficient; therefore, within the social protection programs, it is necessary that the funds that are directly intended for solving this problem should be increased. For these funds to reach those in need, it is necessary that administrative barriers, such as requests for the registration of 
residence, personal documents, etc. should be eliminated. Among poor persons who are entitled to social assistance, there are a significant percentage of those who are illiterate and unfamiliar with the social welfare programs. It is therefore necessary for welfare services to actively assist such persons in achieving their right to social protection.

A social welfare reform in the Republic of Serbia should include the reformulation of the social policy so that it is fair and rational. An equitable social policy contains programs addressing the poorest. On the other hand, they should be fully involved in these programs. For example, the "Thirteenth Pension" social program only covers poor pensioners. However, they make up only $25 \%$ of the total number of the poor in the Republic of Serbia. A rational social policy makes sure that allocations do not threaten the stability of the budget. In the Republic of Serbia, for example, about one-third of the budget funds are allocated for pensions and social assistance, which is not sustainable in the medium term. Therefore, it is necessary that the existing resources be used more rationally (Fiskalni savet Republike Srbije, 2012, 12).

In the forthcoming years, it is necessary that social maps be created in order to finally determine who the poorest citizens are, and thus to enable the social programs to focus on them. The fiscal consolidation realized by increasing taxes, on the one hand, and a real decrease in wages and pensions, on the other, will result in a temporary further deterioration of the standard. Social pressure will be high, and the heavy burden of consolidation would be borne by the public sector employees, which is justified from an economic standpoint, because the public sector wages are higher than those in the private sector, and the risk of losing a job is smaller. Creating social maps would help social assistance to reach users who really need it, on the one hand, while, on the other, there would be a rationalization of the number of users.

It would be preferable to engage the local communities in the social welfare of the poor, which, after the amendment to the Law on the Financing of Local SelfGovernments, have a lot more money, so some of this money could be used for social welfare programs. Local communities could be included in the social protection of those citizens who are in a difficult financial position and do not receive assistance from the state budget. In this case, however, it is necessary to make a selection and do the targeting, so that the limited funding could reach those who are most in need of it. Therefore, a priority should be given to the measures aimed at helping families in extreme poverty, rather than measures not caused by the economic situation of users.

\section{CONCLUSION}

More than a decade after the start of the transition process in the Republic of Serbia, after the initial success, any significant progress has been lacking. According to the transition indicators of the European Bank for Reconstruction and Development and the indicators of international competitiveness by the World Economic Forum, the Republic of Serbia is falling behind successful transition countries and its economic growth is based more on domestic consumption and imports thanks to revenues from privatization and foreign borrowing than on the reforms and competitiveness (Maksimović, 2012). There are estimations that the Republic of Serbia has reached the level that successful countries reached in the 1990s, speaking from the perspective of the business environment, the implemented reforms and the European integration processes.

The Republic of Serbia and other Western Balkan countries are lagging behind in transition and therefore should accelerate the reform process and their integration into the European Union. Without accelerated reforms, it is impossible to increase the credibility of the country and reduce the investment risk. In this context, the public sector reform, the privatization of public enterprises, the development of public-private partnerships and reducing the grey economy and corruption are of particular importance.

In the process of joining the European Union, very complex requirements have been set for the Republic of Serbia, the fulfillment of which requirements being one of the main conditions for further progress in the integration process. Of course, a special emphasis is put on the public sector reform. 
Changes in the public sector have their own institutional, economic, and social aspects. How specific changes in the public sector are can be seen on the examples of the neighboring countries in which people react violently to the raise of the age limit for retirement, the reduction of employment in the public sector, and the privatization of public enterprises. The public sector reforms, including the rationalization of the sector, pension reform, social security and health care, affect all of us and the quality of our lives. Therefore, it is important that these changes be made slowly so as not to lead to a social unrest.

Often, the reform of the public sector is characterized by a painful process of transition, which must be taken into account by economic policy makers. This reform has a significant qualitative aspect. The quality of the public sector in the Republic of Serbia, especially in recent years, has beengaining more and more importance along with the need to modernize public services and the agreed objectives of the public administration reform. The introduction of the economic principles in the evaluation of public services and an increasing focus on the user demands are moving the public sector closer to the business sector. In addition to focusing on the user requests, the necessity of a continuous improvement within the public sector is also significant, which is another thing policy makers have to take into account.

This study has clearly highlighted the direction which the public sector should develop in, which, for the most part, has confirmed the hypothesis that in order for the transition of the Republic of Serbia's economy to successfully complete, it is necessary that a comprehensive reform of the public sector should be carried out. Of course, a number of open issues primarily related to the models and forms of financing the public sector remain of concern to the economic science and profession.

\section{ACKNOWLEDGEMENTS}

The research in this paper was conducted within Project No. 179015 , funded by the Ministry of Science of the Republic of Serbia.

\section{REFERENCES}

Altiparmakov, N., (2013). Unapređenje intergeneracijske pravičnosti i održivosti penzijskog sistema Srbije. Ekonomske ideje i praksa, 4(11), 31-54.

Anđelić, G., i Đaković, V. (2013). Reforma javnog sektora Republike Srbije - pravci, trendovi i izazovi. Poslovna ekonomija, 7(1), 59-78.

Arsić, M. i drugi (2010). Reforma javnog sektora. U Postkrizni model ekonomskog rasta i razvoja Srbije 2011-2020. Beograd, Srbija: Fond za razvoj ekonomske nauke, Ekonomski fakultet Univerziteta u Beogradu

Clark, R. L., Sandler Morrill, M., \& Vanderweide, D. (2014). Defined benefit pension plan distribution decisions by public sector employees, Journal of Public Economics, 116(1), 73-88.

Dimitrijević, M., i Cvetković, Z. (2010). Reforma javnog sektora u Republici Srbiji po modelu javno-privatnog partnerstva. Anali međunarodne konferencije mladih lidera,1(1), 121-130.

Đuričin, S. (2011). Tranzicija i kretanje zaposlenosti u javnom i privatnom sektoru, U J. Zubović (Ur.), Aktione mere na tržištu rada i pitanje zaposlenosti (str. 298-318). Beograd, Srbija: Institut ekonomskih nauka.

Eurostat. (2012). Employment statistics, http://eeurostat. ec.europa.eu/statistics_explained/index.php/Employment_ statistics

Fiskalni savet Republike Srbije. (2012). Mišljenje na predlog Fiskalne strategije za 2013. sa projekcijama za 2014. i 2015.godinu. Beograd, Srbija: Fiskalni savet Republike Srbije.

Hrustić, H., i Dimitrijević, M. (2009). Stanje i perspektive penzijskog osiguranja u Srbiji. Socijalna misao, 16(4), 89-102.

IMF (n.d.) Preuzeto 05.06.2014. sa http://www.imf.org/external/ pubs/cat/longres.aspx?sk=40778.0. Republic of Serbia 2013 Article IV Consultation, Country Report No.13/206.

IMF (n.d.) Preuzeto 06.06.2014. sa http://elibrary-data.imf. org/FindDataReports.aspx?d=33061\&e=170809 Government Finance Statistics (GFS) - eLibrary Data,

Institut za javno zdravlje Srbije. (2011). Svrsishodnost i potreba razvoja sistema NZR, Analiza kretanja rashoda za zdravstvenu zaštitu. www.batut.org.rs

Institut za javno zdravlje Srbije. (2012). Odabrani zdravstveni pokazatelji za 2011. godinu. www.batut.org.rs.

Krstić, B., Stevanović, T., i Džunić, M. (2011). Određeni aspekti merenja performansi u organizacijama javnog sektora. 
Ekonomske teme, 49(3), 433-448.

Maksimović, Lj. (2012). Sistemska ograničenja konkurentnosti privrede Srbije. Ekonomski horizonti, 14(2), 99-109. doi:10.5937/ ekonhor1202099M

Mihajlović, M., Mihić, S., i Rađenović, D. (2013). Restruktuiranje javnih preduzeća u Srbiji - usmeravanje ka tržišnim principima poslovanja. Poslowna ekonomija, 7(1), 157-176.

Ministarstvo finansija Republike Srbije. (2011). Analiza poslovanja javnih preduzeća u 2010. godini. Beograd.

Ministarstvo finansija Republike Srbije. (2013a). Informacija o paketu mera za stabilizaciju javnih finansija i oporavak privrede. Beograd.

Ministarstvo finansija Republike Srbije. (2013b). Bilten javnih finansija. Beograd, 17(decembar), 4-38.
Petrović, (2009). Efekat svetske finansijske krize na Srbiju i odgovor ekonomske politike. Ekonomika preduzeća, 57(1-2), 43-50.

Raičević, B. (2008). Javne finansije. Beograd, Srbija: Ekonomski fakultet Univerziteta u Beogradu.

Republički fond za penzijsko i invalidsko osiguranje. (2012). Statistički godišnji bilten. www.pio.rs/cir/

Republički zavod za statistiku. (2013). Anketa o radnoj snazi. http://webrzs.stat.gov.rs/WebSite/

Veselinović, (2007). Stanje reformi i prioriteti ekonomske politike Srbije. Ekonomski horizonti, 9(1/2), 53-72.

Zakon o jaonim preduzećima, Službeni glasnik Republike Srbije, br. 119/2012, br. 116/2013, br. 44/2014 - dr.zakon.

Received on $13^{\text {th }}$ June 2014, after two revisions, accepted for publication on $19^{\text {th }}$ August 2014.

Petar Veselinovic is an Associate Professor at the Faculty of Economics, University of Kragujevac, Serbia, where he received his $\mathrm{PhD}$ degree in General Economics and Economic Development. The areas of his scientific research are economic system, macroeconomic policies and regional development. He has authored and coauthored six university textbooks and monographs as well as 130 scientific papers published in international and national scientific journals and presented at conferences. 


\title{
REFORMA JAVNOG SEKTORA KAO KLJUČNA DETERMINANTA USPEŠNOSTI TRANZICIJE PRIVREDE REPUBLIKE SRBIJE
}

\author{
Petar Veselinović* \\ Ekonomski fakultet Univerziteta u Kragujevcu
}

\begin{abstract}
Privreda Republike Srbije danas se nalazi na važnoj prekretnici. Prva faza sprovođenja tranzicionih procesa je završena, reformski procesi dobijaju novi zamah, a ulazak u Evropsku uniju postaje sve izvesniji. Da bi se tranzicioni procesi uspešno priveli kraju, neminovna je, između ostalih reformi, i reforma javnog sektora. Javni sektor u Republici Srbiji je nisko produktivan i neefikasan, neracionalno postavljen sa mnoštvom problema koji se godinama uvećavaju i usložnjavaju. Visoka stopa zaposlenosti i relativno visoke plate u javnom sektoru, s jedne, i loše formulisani poslovni sistemi, s druge strane, čine da tako koncipiran javni sektor nepovoljno utiče na ekonomski razvoj u celini. U radu će biti analizirano stanje u javnom sektoru Republike Srbije, sa posebnim akcentom na stvaranje realnih osnova za njegovu reformu kao ključnu determinantu uspešnog okončanja procesa tranzicije, uz uvažavanje specifičnosti koje ima privreda Republike Srbije.
\end{abstract}

Ključne reči: tranzicija, reforma javnog sektora, poslovni ambijent, penzioni sistem, socijalna zaštita

JEL Classification: $\mathrm{H} 10, \mathrm{H} 55, \mathrm{H} 60$

\section{UVOD}

Bez aktivnosti koje su u nadležnosti javnog sektora ne može se zamisliti nijedno razvijeno demokratsko društvo, s obzirom na to da one obuhvataju uspostavljanje i održavanje pravnog poretka, proizvodnju javnih dobara, javno obrazovanje, javnu zdravstvenu zaštitu, zaštitu starih lica, zaštitu siromašnih, subvencionisanje određenih privrednih grana, izgradnju infrastrukture, podsticanje naučnih istraživanja i sl. Efikasno funkcionisanje javnog

\footnotetext{
* Korespondencija: P. Veselinović, Ekonomski fakultet Univerziteta u Kragujevcu, Đ. Pucara 3, 34000 Kragujevac, Srbija; e-mail: pveselinovic@kg.ac.rs
}

sektora važan je faktor održavanja makroekonomske stabilnosti, privrednog rasta, standarda stanovništva i društvenog blagostanja. Odsustvo takve karakteristike funkcionisanja javnog sektora izvor je ozbiljnog narušavanja funkcionisanja privrede $\mathrm{u}$ celini.

Veličina javnog sektora Republike Srbije ne odgovara nivou bruto domaćeg proizvoda (BDP), a svaka njegova promena, pozitivna ili negativna, direktno utiče na stanje $\mathrm{u}$ privredi. Veza javnog sektora i privrednog sistema je dvosmerna i usko uslovljena. Efikasan javni sektor doprinosi razvoju ukupne privrede, i obrnuto.

Pitanje reforme javnog sektora godinama se već apostrofira kao jedan od imperativa uspešnog 
okončanja tranzicije i stvaranja povoljnog ambijenta za uspešan privredni razvoj. Racionalizacija, smanjenje plata, reorganizacija javnog sektora kao i restrukturiranje javnih preduzeća bitni su postulati održivosti nacionalne privrede. Pri svemu tome, država ne sme da zanemari ni socijalni aspekt života građana, naročito, kroz reformu zdravstvenog sistema, penzijskog sistema i sistema socijalne zaštite.

Predmet istraživanja ovog rada usmeren je na ukazivanje na značaj reforme javnog sektora u sklopu procesa tranzicije privrede Republike Srbije. Shodno tome, cilj rada je definisanje ključnih pravaca, odnosno, segmenata reforme javnog sektora u Republici Srbiji. Polazeći od definisanog predmeta i cilja istraživanja, pristupiće se testiranju glavne hipoteze istraživanja koja glasi: Ukoliko se želi uspešan završetak procesa tranzicije privrede Republike Srbije, neophodno je sprovesti sveobuhvatnu reformu javnog sektora.

U skladu sa definisanim predmetom i ciljem istraživanja, pored uobičajene metodologije koja se koristi u ekonomskim istraživanjima, u radu će biti korišćen metod komparativne analize.

Da bi se tranzicioni procesi u Republici Srbiji uspešno priveli kraju, neminovna je promena sistema funkcionisanja javnog sektora, u funkciji kontinuiranog unapređivanja njegovog rada. To je jedan od bitnih preduslova za privredni oporavak i trend pozitivnog razvoja ekonomskog sistema u celini. Da bi se razumela važnost reforme javnog sektora, kao ključne determinante tranzicije, neophodno je objasniti osnovne komponente i karakteristike javnog sektora. U ovom radu biće analizirani podaci o broju i strukturi javnih preduzeća, uz navedene probleme koji prate javni sektor, $\mathrm{u}$ prvom redu permanentno povećanje javnog duga izazvano fiskalnim deficitom i garancijama koje država daje na zaduživanje javnih preduzeća. Uz analizu postojećeg stanja, biće prezentovane i konkretne mere koje bi trebale da dovedu do uspešne reforme javnog sektora Republike Srbije.

Rad je, pored uvoda i zaključnih razmatranja, koncipiran $\mathrm{u}$ tri dela. $\mathrm{U}$ prvom delu biće istaknute osnovne karakteristike javnog sektora Republike Srbije, u drugom će biti ukazano na neophodnost njegove reforme i u poslednjem, trećem, delu, na ključne segmente reforme javnog sektora: prestrukturiranje javnih preduzeća, reformu penzijskog sistema, reformu sistema zdravstvene zaštite i reformu sistema socijalne zaštite.

\section{OSNOVNE KARAKTERISTIKE JAVNOG SEKTORA REPUBLIKE SRBIJE}

Preduzeti reformski procesi u privredi Republike Srbije samo su još jedan primer da dobri inicijalni rezultati nisu održivi bez korenitih promena $u$ institucionalnom ambijentu privređivanja. Naime, još nije $\mathrm{u}$ potpunosti kreirana stabilna institucionalna infrastruktura kojom se stvara poslovni ambijent podsticajan za dugoročno povećavanje proizvodnje, zaposlenosti, investicija i izvoza. Takva institucionalna infrastruktura podrazumeva jasno koncipirana, dugoročna i konzistentna privrednosistemska rešenja u svim oblastima privređivanja (Veselinović, 2007, 54). Javni sektor je jedna od tih oblasti.

Javni sektor je deo nacionalne privrede koji obuhvata opšti nivo države kao i nefinansijska preduzeća pod kontrolom države (javna preduzeća) koja se primarno bave komercijalnim aktivnostima. Ovaj sektor obuhvata preduzeća koja obavljaju delatnosti od opšteg interesa za sve građane: elektroprivreda, naftna industrija, svi oblici transporta, PTT saobraćaj, komunalne službe. Kao osnivač ovih preduzeća javlja se država, odnosno, jedinice lokalne samouprave.

Javni sektor Republike Srbije ima svoju dugu istoriju koja datira još iz perioda socijalističkog uređenja države i društva. U tom periodu, javni sektor je predstavljao "produženu ruku“ države i preko njega je direktno ostvarivan njen uticaj na zbivanja $u$ nacionalnoj ekonomiji.

Javni sektor Republike Srbije čini veliki broj javnih preduzeća, pa stoga on može da se posmatra u užem i širem kontekstu. U užem kontekstu, javni sektor Republike Srbije čine javna preduzeća čiji je osnivač Republika, javna preduzeća čiji je osnivač pokrajina, i komunalna javna preduzeća, dok širi kontekst javnog sektora, pored navedenih javnih preduzeća, čine i 
sva druga privredna društva i pojedinci koji direktno i indirektno posluju sa tim javnim preduzećima (Anđelić i Đaković, 2013, 60).

Ne postoje zvanični podaci o broju zaposlenih $\mathrm{u}$ javnom sektoru Republike Srbije ali, sve relevantne procene ukazuju da je više od 700000 radnika direktno ili indirektno zaposleno $\mathrm{u}$ ovom sektoru što, $\mathrm{u}$ odnosu na ukupan broj zaposlenih od 1698000 radnika, predstavlja značajno učešće.

Značaj javnog sektora u Republici Srbiji može se ilustrovati i sledećim podacima (Arsić i drugi, 2010, 143):

- putem poreza i javne potrošnje preraspodeljuje se preko $40 \%$ bruto domaćeg proizvoda Republike Srbije;

- javne investicije učestvuju sa $15 \%$ u ukupnim investicijama.

Delatnosti i funkcije države i javnog sektora uobičajeno nazivamo javnim potrebama. Naime, pojedinac je sposoban da sopstvenim sredstvima obezbedi sebi stanovanje, hranu, odeću, odnosno, da zadovolji deo ličnih potreba. Međutim, unutrašnja i međunarodna bezbednost, zdravstvena zaštita, obrazovanje, kultura, socijalna sigurnost, i niz drugih civilizacijskih tekovina modernog društva, zavise od postojanja organizovanog delovanja državnih organa i javnih institucija.

Osnovna karakteristika javnog sektora u Republici Srbiji jeste niska efikasnost i visok nivo troškova, $\mathrm{u}$ poređenju sa kvalitetom i obimom usluga koje taj sektor pruža.

Logika funkcionisanja i organizovanja javnog sektora u Republici Srbiji nije se vremenom značajno promenila, iako je društvo prolazilo kroz velike promene. Pitanje koje se nameće kao logično jeste zašto se to nije desilo? Zašto javni sektor Republike Srbije nije prolazio kroz promene koje su bile neophodne? Zašto se nije prilagođavao promenama društvenog uređenja, društvene svesti i novim tržišnim tokovima? Odgovor zavisi od toga šta je $u$ fokusu analiziranja. Ukoliko se kao osnovni predmet analize postavi društvena svest pojedinaca u Republici Srbiji, onda se može konstatovati da razlog nemenjanja javnog sektora leži u ambiciji vlasti da zadrži nepromenjeno stanje, a javni sektor joj u toj ambiciji može značajno pomoći. Ako se kao osnovni predmet analize postavi ekonomska stabilnost, onda se kao razlog nemenjanja javnog sektora može definisati želja vlasti da preko prividne ekonomske stabilnosti zadrži svoje pozicije u državi. I, na kraju, otpor promenama u okviru javnog sektora je, takođe, jedan od značajnih razloga njegovog nemenjanja.

Sociološki gledano, stanje i prilike u javnom sektoru bi trebalo da prate stanja i prilike u državi. U Republici Srbiji to nije slučaj. Ukoliko se analizira period od početka devedesetih godina XX veka, onda se može zaključiti da i u najtežim periodima za Republiku Srbiju, stanje i prilike u javnom sektoru, za one koji su u njemu zaposleni i one koji ostvaruju direktnu ili indirektnu saradnju sa njim, nisu bili loši u odnosu na sektor privrede koji je u privatnoj svojini. Veliki broj javnih preduzeća poslovao je, ili i dalje posluje sa gubicima a, pri tom, zaposleni u tim preduzećima imaju položaj koji je značajno iznad proseka privrede kao celine. Praksa pokazuje da su javna preduzeća najveći gubitaši, a da ta ista javna preduzeća redovno isplaćuju visoke zarade zaposlenima.

U definisanju javnog sektora Republike Srbije interesantno je analizirati odnos broja i strukture javnih preduzeća između pojedinih nivoa vlasti. U široj javnosti se najčešće kao primeri javnih preduzeća i javnog sektora uopšte navode ona koja pripadaju republičkom nivou. Međutim, ukoliko se pogleda struktura javnog sektora Republike Srbije, onda se može uočiti da je raspodela broja javnih preduzeća u Republici Srbiji prilično heterogena i da je veliki broj javnih preduzeća prisutan kako na lokalnom, tako i na republičkom i pokrajinskom nivou vlasti.

Javni sektor Republike Srbije je preveliki i kao takav proizvodi negativne efekte na celu privredu. Visoki troškovi koje generiše javni sektor predstavljaju ozbiljan problem budžetskoj ravnoteži i upravo je nivo budžetskog deficita jedan od najznačajnijih problema ekonomske politike Republike Srbije. Skupa država direktno podiže troškove u privredi i time destimulativno deluje na tekuće poslovanje, kao i na investiciono ponašanje domaćih i stranih preduzeća. 
U većini javnih preduzeća malo je mogućnosti da se determiniše optimalan nivo trošenja (ulaganja). U takvim situacijama odgovorna lica nastoje da potroše onoliko koliko odobreni budžet dozvoljava, iako predviđeni iznosi u budžetu mogu biti viši u odnosu na objektivno potrebne iznose trošenja. Iz tog razloga, mnoga javna preduzeća imaju obeležje operativno neefikasnih organizacija, pa je opravdana potreba da se ovako gledanje promeni (Krstić, Stevanović i Džunić, 2011, 434).

Ključni problemi u javnom sektoru Republike Srbije su:

- visoki troškovi državne uprave i javnih službi u vidu mase zarada zaposlenih i njihovog učešća u bruto domaćem proizvodu;

- ustaljena praksa formiranja raznih državnih agencija i sličnih institucija, bez prethodne procene postojeće infrastrukture i ocene da li $\mathrm{u}$ državi već postoji organizacija koja te poslove radi ili ima kapacitete da ih obavlja;

- neracionalno trošenje budžetskih sredstava subvencionisanjem neefikasnih javnih preduzeća;

- neefikasni sistemi penzijskog osiguranja, socijalne i zdravstvene zaštite i obrazovanja;

- neefikasna i birokratizovana administracija koja podstiče privatni sektor na sivu ekonomiju.

Poseban problem je neefikasnost javnih preduzeća. Analiza finansijskih izveštaja za period od 2007. do 2011. godine pokazuje da su, osim u prvoj godini posmatranog perioda, javna preduzeća u Republici Srbiji poslovala sa neto gubitkom. Njegov najveći iznos zabeležen je u 2009. godini. U ukupnom neto finansijskom rezultatu privrede, tj. neto gubitku, javna preduzeća, posmatrana zajedno, učestvovala su sa oko 1/4 (Ministarstvo finansija Republike Srbije, 2011, 19).

Formiranje cena usluga $u$ javnom sektoru sadrži socijalnu komponentu koja ne obezbeđuje ekonomsku održivost, a mehanizmi naplate potraživanja su neefikasni. Upravljanje $u$ većini ovih preduzeća je neefikasno i pod uticajem političkih partija.

Da bi se bolje shvatila neophodnost mera usmerenih na reformu javnog sektora Republike Srbije, potrebno je sagledati, na prvom mestu, veličinu javnog sektora u Republici Srbiji i uporediti ga sa podacima drugih zemalja. Takođe, bitno je sagledati kako se kreću prosečne zarade zaposlenih u ovom sektoru.

U analizi javnog sektora, ključno pitanje je koja veličina i struktura čini ovaj sektor efikasnim. Ćinjenica je da ne postoji jedinstvena, optimalna veličina javnog sektora za sve zemlje, jer svaka zemlja u određenom razdoblju treba da proceni optimalnu veličinu javnog sektora.

S obzirom na to da ne postoji jedinstvena metodologija na međunarodnom nivou koja bi omogućila poređenje veličine javnog sektora po državama, upotrebićemo pokazatelj učešća broja zaposlenih u javnom sektoru u ukupnom broju zaposlenih. Za aproksimaciju veličine javnog sektora po zemljama korišćeni su podaci o broju zaposlenih u delatnostima državne uprave, odbrane, obaveznog socijalnog osiguranja, zdravstvene i socijalne zaštite i obrazovanja (Ministarstvo finansija Republike Srbije, 2013a, 24).

Po ovom pokazatelju (Slika 1), javni sektor u Republici Srbiji ne odstupa od istog u odabranim zemljama Evropske unije. To, naravno, ne znači da je njegova veličina optimalna, niti je isključena mogućnost da zaposlenih u nekim segmentima javnog sektora ima previše, dok ih u drugim nedostaje.

Slika 1 pokazuje da, po broju zaposlenih $\mathrm{u}$ javnom sektoru u 2012. godini, Republika Srbija prednjači u odnosu na zemlje u okruženju - Bugarska, Rumunija i Češka, ali ima manje zaposlenih u javnom sektoru od pojedinih članica EU - Litvanija, Estonija, Letonija, Slovenija, Poljska, Mađarska i Slovačka.

I drugi pokazatelj veličine javnog sektora, tj. učešća javnih rashoda u bruto domaćem proizvodu (Slika 2), ukazuje na to da javni sektor Republike Srbije ne odstupa mnogo od javnog sektora u drugim zemljama. Javni sektor u Republici Srbiji troši približno koliko i javni sektor u Češkoj i Poljskoj, a nešto više nego javni sektor u Bugarskoj, Rumuniji, Hrvatskoj i Turskoj.

Prikazane podatke potrebno je dopuniti podacima o strukturi javnih rashoda. U Republici Srbiji, izdaci na plate zaposlenih $u$ javnom sektoru i penzije učestvuju u ukupnim javnim rashodima sa više od 50\% (u 2011. godini učešće je iznosilo 52,4\%). Iznos javnih rashoda 


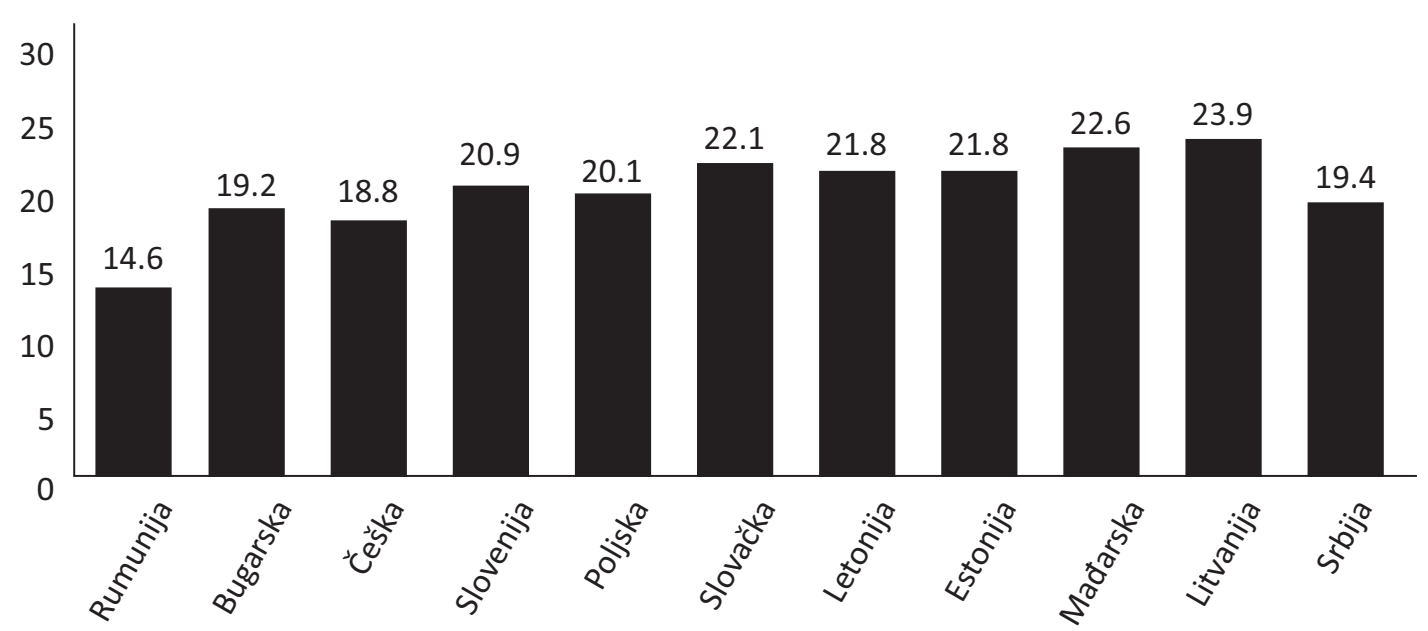

Slika 1 Učešće broja zaposlenih u javnom sektoru u ukupnom broju zaposlenih u 2012. (u\%)

Izvor: Autor, na osnovu: Eurostat, 2012; Republički zavod za statistiku, 2013

na ime penzija za oko 1600000 penzionera u 2011. godini je bio za $23 \%$ veći od iznosa na ime rashoda za oko 470.000 zaposlenih u državnoj upravi i javnim službama. U isto vreme, učešće kapitalnih rashoda u javnim rashodima se kreće oko 8\%. Reč je o sredstvima za održavanje postojećih i pokretanje novih javnih

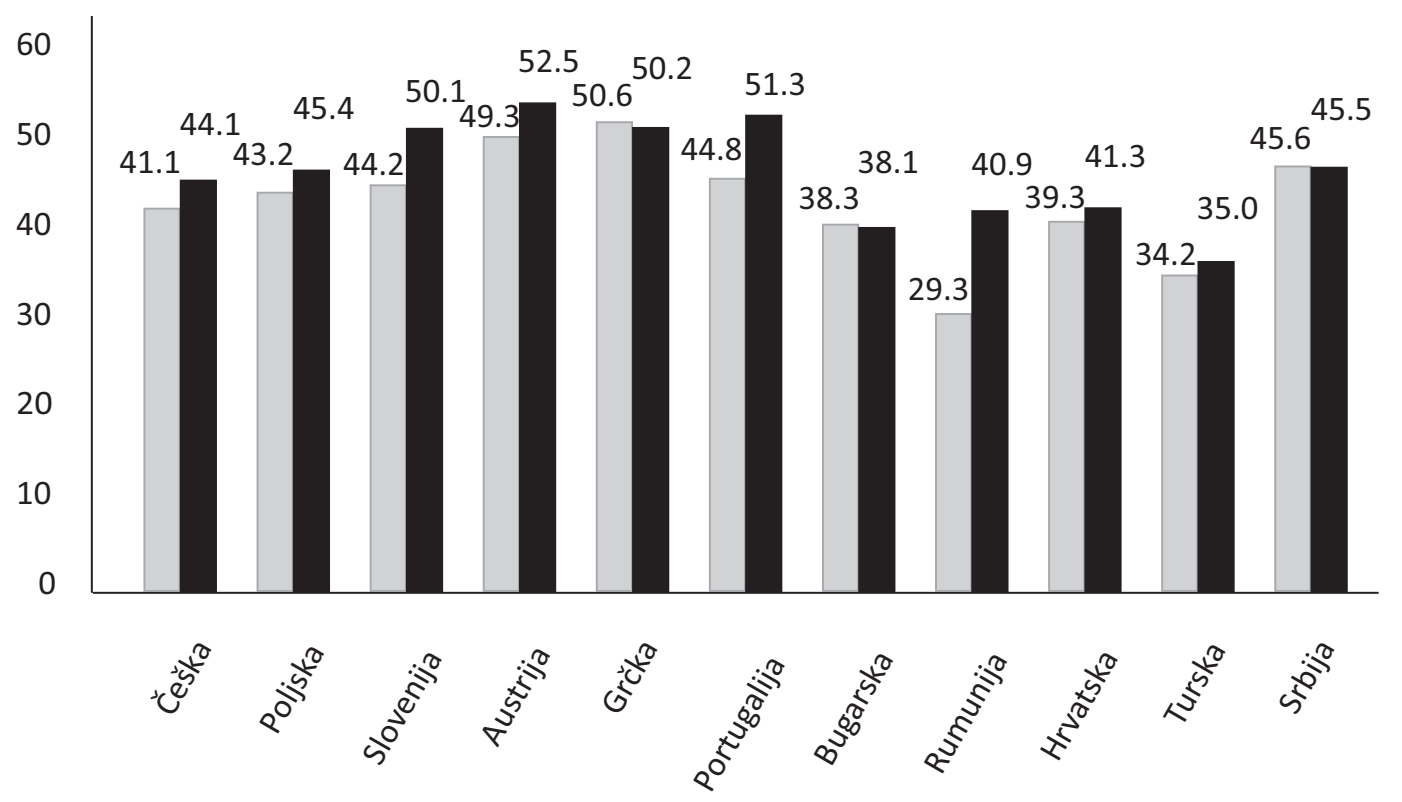

Slika 2 Učešće javnih rashoda u bruto domaćem proizvodu (u\%) 
investicija i iznos je manji od rashoda na ime kupovine roba i usluga (za tekuću državnu potrošnju) koji u ukupnim javnim rashodima učestvuju oko $16 \%$. Učešće naknada za zaposlene $\mathrm{u}$ javnom sektoru $\mathrm{u}$ bruto domaćem proizvodu Republike Srbije je na nivou učešća ovih naknada u Hrvatskoj i Poljskoj, ali iznad nivoa učešća u Bugarskoj, Rumuniji, Austriji ili Češkoj.

Uzimajući $\mathrm{u}$ obzir proces tranzicije $\mathrm{u}$ Republici Srbiji i njegov uticaj na tržište radne snage, često je ispitavan i odnos zaposlenosti $u$ javnom i realnom sektoru. Poznato je da je tranzicija uticala na pad bruto domaćeg proizvoda, rast inflacije, ali i na tržište rada koje karakteriše visoka nezaposlenost, nisko učešće zaposlenosti u privatnom sektoru i nedovoljna mobilnost radne snage (Đuričin, 2011, 234-260). Zato se u mnogobrojnim radovima ističe značaj jačanja privatnog sektora kao pokretačke snage tržišta rada, sa posebnim akcentom na što efikasnije korišćenje potencijala sektora malih i srednjih preduzeća.

Prosečna zarada zaposlenih $\mathrm{u}$ javnom sektoru je iznad prosečne zarade u Republici Srbiji (Tabela 1). Prosečna neto zarada u Republici Srbiji repubje tek na nivou 70\% prosečne neto zarade $u$ javnim državnim preduzećima, odnosno, $78,5 \%$ iste u državnoj upravi. uer

Tabela 1 Prosečne neto zarade u Republici Srbiji u privatnom i javnom sektoru (u dinarima)

\begin{tabular}{lccccc}
\hline & 2009. & 2010. & 2011. & 2012. & 2013. \\
\hline $\begin{array}{l}\text { Prosečne } \\
\text { neto zarade } \\
\text { (ukupno) }\end{array}$ & 31.733 & 34.142 & 37.976 & 41.377 & 44.182 \\
$\begin{array}{l}\text { Prosečne } \\
\text { neto zarade } \\
\text { u javnom } \\
\text { sektoru }\end{array}$ & 38.885 & 39.810 & 43.506 & 46.551 & 48.969 \\
$\begin{array}{l}\text { Prosečne } \\
\text { neto zarade } \\
\text { u privatnom } \\
\text { sektoru }\end{array}$ & 24.581 & 28.474 & 32.446 & 36.203 & 39.395 \\
\hline
\end{tabular}

Izvor: Ministarstvo finansija Republike Srbije, 2013b, 30-33
Kao opravdanje za veće zarade $u$ javnom $u$ odnosu na privatni sektor se najčešće navodi viši nivo kvalifikacija zaposlenih u javnom sektoru. Međutim, i unutar samog javnog sektora su prisutne značajne razlike u nivou zarada za isti stepen kvalifikacija, što čini nužnim uspostavljanje jasnih principa u sistemu određivanja plata, odnosno ujednačavanje plata za isti stepen kvalifikacija. Na osnovu podataka iz Tabele 1, na Slici 3 je prikazana disproporcija zarada u privatnom i javnom sektoru Republike Srbije.

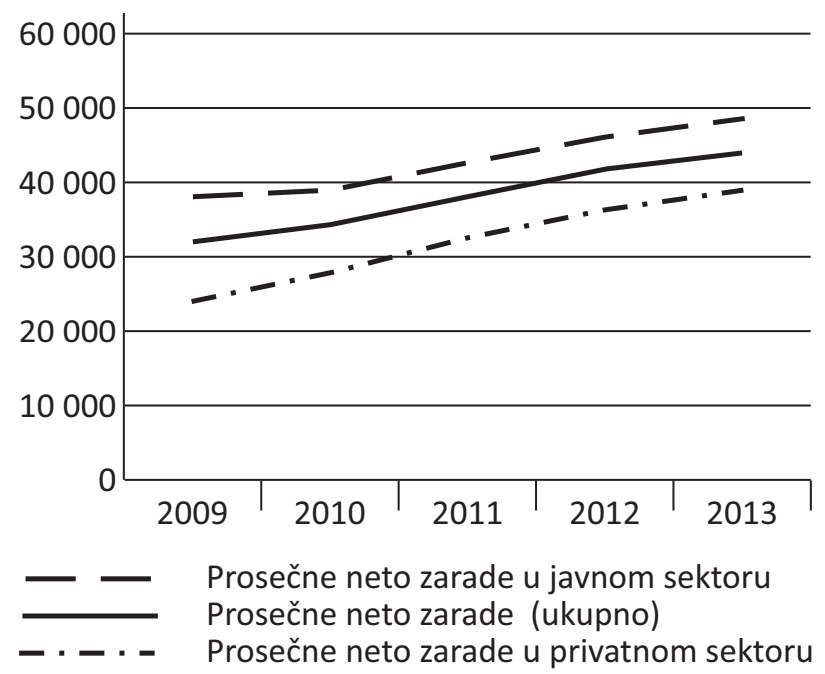

Slika 3 Prosečne neto zarade u Republici Srbiji

Izvor: Autor

Prema podacima Republičkog zavoda za statistiku, u periodu od 2009. do 2013. godine, zarade u javnom sektoru, u Republici Srbiji su bile $28 \%$ veće u odnosu na prosek u privatnom sektoru, a u nekim preduzećima čak i mnogostruko veće: "Srbijavodama” i Aerodromu "Nikola Tesla" 190\%, „Telekomu“ 180\%, „Srbijagasu” 160\%. Prosečna zarada u javnom sektoru u julu 2013. godine iznosila je 48969 dinara, dok je prosečna plata u istom periodu, $\mathrm{u}$ privatnom sektoru, iznosila svega 36257 dinara. Plate $u$ javnom sektoru $u$ odnosu na privatni veće su i u zemljama regiona, ali ne baš kao u Republici Srbiji: u Rumuniji 20\%, Bugarskoj 19\%, 
Slovačkoj 15\%, Mađarskoj 8\%. U Republici Srbiji se na plate $\mathrm{u}$ javnom sektoru troši oko $13 \%$ bruto domaćeg proizvoda, što je duplo više nego u Slovačkoj ili Sloveniji.

\section{NEOPHODNOST REFORME JAVNOG SEKTORA REPUBLIKE SRBIJE}

Pitanje reforme javnog sektora je jedno od osnovnih pitanja reformskog procesa $\mathrm{u}$ privredama zemalja $\mathrm{u}$ tranziciji. Poslednjih decenija došlo je do značajnih promena na tržištu, u smislu načina funkcionisanja, informisanja, povezivanja i efektuiranja, što sve za posledicu ima potrebu redefinisanja mesta, uloge i značaja javnog sektora u tržišnim tokovima. Specifičnost reforme javnog sektora zemalja u tranziciji jeste da ona, u velikom broju zemalja, ili nije ni počela, ili se odvija veoma sporo.

Reformu javnog sektora Republike Srbije treba posmatrati kao kontinuiranu, sistemsku aktivnost, usmerenu ka jasnom opredeljenju kakav javni sektor je potreban Republici Srbiji. U tom smislu, definisanju konkretnih pravaca i mera reforme javnog sektora Republike Srbije treba da prethodi detaljna analiza aktuelnog stanja, kako bi se dobila jasna i pouzdana predstava o stanju u kome se celokupan društvenoekonomski sistem Republike Srbije nalazi. Ova analiza treba da obuhvati, između ostalih, sledeće aspekte:

- ekonomski aspekt (kakvo je zatečeno ekonomsko stanje tržišnih subjekata i koji su mogući izvori njegovog poboljšanja);

- institucionalni aspekt (koje propise je potrebno prilagoditi i promeniti da bi se reforma uspešno sprovela);

- socijalno-psihološkiaspekt (kakvo je raspoloženje stanovništva po pitanju spremnosti za reformu celokupnog društveno-ekonomskog sistema, pa u okviru toga i javnog sektora).

Kada sagledamo ove aspekte, onda možemo da govorimo i o mogućim pravcima reforme javnog sektora Republike Srbije. Jasno je da oni trebaju biti usmereni ka:
- korporatizaciji javnog sektora,

- većoj zastupljenosti javno-privatnog partnerstva, i

- kombinaciji prethodna dva modela.

Kada govorimo o korporatizaciji javnog sektora Republike Srbije, ona podrazumeva institucionalno redefinisanje javnog sektora u smeru kreiranja javnih društava, a što bi za svoju posledicu imalo i redefinisanje organizacionog i upravljačkog pristupa u tim kompanijama. Prednosti ovog pristupa se ogledaju $\mathrm{u}$ tome što bi se poslovanje javnog sektora u većoj meri prilagodilo tržišnim potrebama, a jedan od osnovnih nedostataka leži u potencijalnoj opasnosti od menjanja vlasničke strukture i uticaja privatnog kapitala na njegovo funkcionisanje. Ta okolnost bi mogla da stvori izvesne izazove, jer je poznato da je interes privatnih investitora i države vrlo često različit (investitori se, pre svega, rukovode motivom maksimizacije profita, a država bi, po svojoj prirodi, trebalo da vodi računa i o socijalnim i drugim potrebama). Pa ipak, ovaj model bi mogao da doprinese porastu produktivnosti i efikasnosti u javnom sektoru, jer bi se jasno mogla utvrditi odgovornost u poslovanju. Ukoliko bi se, zajedno sa implementacijom ovog modela, insistiralo i na potpunoj profesionalizaciji upravljačke funkcije $\mathrm{u}$ javnom sektoru, ovaj model bi mogao da pruži zadovoljavajuće rezultate.

Javno-privatno partnerstvo jeste model o kome se dugo govori i piše. Iskustva razvijenih zemalja potvrđuju tezu da je za određene delatnosti koje su obuhvaćene javnim sektorom ovaj model je primeren. Postavlja se, međutim, pitanje mogućnosti implementacije ovoga modela u Republici Srbiji?

Javno-privatno partnerstvo je dugoročan ugovorni partnerski odnos između javnog i privatnog sektora, koji može da uključuje: projektovanje, finansiranje, izgradnju, upravljanje ili pružanje usluga od strane privatnog sektora, koje tradicionalno pruža javni sektor. Naime, radi se o modelu koji donosi koristi za obe strane i podrazumeva uspešniju kombinaciju ciljeva javnog i privatnog sektora. Javno-privatno partnerstvo je zajedničko korporativno delovanje javnog i privatnog sektora čiji je cilj ekonomičnija, delotvornija i uspešnija proizvodnja javnih dobara ili usluga $u$ odnosu na tradicionalan način njihovog 
obezbeđenja. Javni sektor se tom prilikom javlja kao partner koji ugovorno definiše vrste i obim poslova ili usluga koje namerava da prenese na privatni sektor. Privatni sektor se javlja kao partner koji zahteva takvu saradnju, ukoliko može da se ostvari profit, i koji je dužan da kvalitetno izvršava ugovorom dobijene i definisane poslove (Dimitrijević i Cvetković, 2010, 121130).

Kombinujući prethodna dva modela dobila bi se značajna fleksibilnost i mogućnost adaptibilnosti ponuđenih rešenja, uz puno uvažavanje specifičnosti javnog sektora Republike Srbije na republičkom, pokrajinskom i lokalnom nivou. $S$ druge strane, postoji objektivna opasnost da se ovakav, kombinovani pristup pokaže kao neprimenljiv, jer društvenoekonomski sistem Republike Srbije, još uvek, nije spreman za takvo uređenje javnog sektora. Čini se da bi kombinacija dva gore navedena modela za Republiku Srbiju bila optimalno rešenje, ali se to ne može tvrditi sa sigurnošću sve dotle dok se ne realizuju neophodne analize stanja i prilika na tržištu Republike Srbije, sa projekcijom očekivanih trendova.

Reforma javnog sektora je neiscrpna tema poslednjih godina. Višegodišnja politizacija javnog sektora, neracionalna ekonomska, kadrovska i uopšte, poslovna politika, nerazumevanje položaja javnog sektora u modernom društvu, nespremnost države da na racionalnim osnovama započne njegovu reformu, samo su neki od razloga koji za svoju posledicu imaju nisko produktivan i potkapitalizovan javni sektor. Globalna ekonomska kriza dodatno je pogoršala stanje na ovom području, a reakcija ekonomske politike bila je neadekvatna. Reakcija fiskalne i monetarne politike bila je nekoordinirana, uglavnom iznuđena, a delom kao da krize nema. Fiskalna politika, pod pritiskom političke elite ispunjava deo populističkih predizbornih obećanja i uprkos krizi povećava javnu potrošnju (Petrović, 2009, 43).

Sve navedeno pokazuje da je nužno raščistiti sa nasleđem iz prethodnog perioda i, prema uzoru na zemlje koje imaju dobro postavljen javni sektor, osmisliti i sprovoditi reformu javnog sektora Republike Srbije. Poznato je da stabilan javni sektor predstavlja osnov razvoja zemlje i njegov temelj na kome počiva dugoročni privredni napredak, dok nestabilan javni sektor usporava razvojne tendencije.

\section{KLJUČNI SEGMENTI REFORME JAVNOG SEKTORA REPUBLIKE SRBIJE}

Shodno prethodnoj analizi, možemo uočiti da je reforma javnog sektora Republike Srbije kompleksan proces koji treba da obuhvati: restrukturiranje javnih preduzeća, reformu penzijskog sistema, reformu zdravstvenog sistema i reformu sistema socijalne zaštite.

U naučnoj i stručnoj javnosti različito se definiše pojam ,jjavnog preduzeća“, pa se postavlja pitanje šta je to javno i zašto je javno? Zakon o javnim preduzećima definiše pojam javnog preduzeća na način da je javno preduzeće ono preduzeće koje obavlja delatnost od opšteg interesa, a koje osniva država, odnosno, jedinica lokalne samouprave ili autonomna pokrajina. Međutim, u Zakonu o javnim preduzećima vidi se da delatnosti od opšteg interesa mogu obavljati i druga preduzeća, odnosno, drugi preduzetnici i oblici preduzeća.

Prema zakonodavstvu Republike Srbije, javna preduzeća mogu da posluju sredstvima u državnoj svojini, privatnoj i drugim oblicima svojine. To su preduzeća koja obavljaju privrednu delatnost od javnog interesa. Predmet njihove delatnosti su proizvodi koje nazivamo javnim dobrima ili javnim uslugama. Pod javnim dobrom podrazumeva se svako dobro koje je proizvedeno $\mathrm{u}$ domenu javne privrede. Karakteriše se nerivalitetom i neekskluzivnošću. Nerivalitetet znači da je, pri bilo kom stepenu ekonomskog iskorišćavanja, nemoguće isključiti iz potrošnje bilo koje druge individualne potrošače. Neekskluzivnost znači da dobro namenjeno nekom pojedincu ili grupi mogu koristiti i drugi, uz vrlo mali ili nikakav dodatni trošak.

U Republici Srbiji je registrovano 715 javnih i javnokomunalnih preduzeća koja se nalaze na spisku Narodne banke Srbije. U Agenciji za privredne registre, kao aktivna privredna društva registrovano je njih 703 (pet je u procesu registracije, pet u stečajnom i dva u likvidacionom postupku). Preduzeća poput 
"Srbijagasa", „Železnice Srbije“, „Puteva Srbije“, Elektroprivreda Srbije, „Pošte Srbije“, Elektromreže Srbije, Aerodroma "Nikola Tesla“, „Telekoma Srbija“, "Srbijašume”, „Srbijavode“, "Vojvodinašume“ i slično, zapošljavaju značajan broj lica, raspolažu velikom imovinom i od vitalne su važnosti za celokupni privredni sistem Republike Srbije.

Ostvareni gubici iskazani u završnim računima većine javnih preduzeća ukazuju na zabrinjavajuće stanje u kojima se ona nalaze. Neadekvatno upravljanje i dugogodišnji pokušaji da se balansira između socijalnog i tržišnog načina poslovanja doveli su ova preduzeća u nezavidnu finansijsku situaciju.

Najveći problemi sa kojima se suočavaju javna preduzeća u Republici Srbiji su:

- veliki politički uticaj na izbor članova upravnih i nadzornih odbora, što za posledicu ima slabo korporativno upravljanje i loše poslovne rezultate;

- gubici koji se kumuliraju godinama, što ugrožava investicije i razvojne mogućnosti ovog tipa preduzeća;

- vrlo niska efektivnost i efikasnost menadžmenta, što se odražava na kvalitet $\mathrm{i}$ asortiman proizvoda $\mathrm{i}$ usluga ovih preduzeća;

- finansijska neravnoteža - javna preduzeća posluju nelikvidno i imaju visoke stope zaduženosti, što je, značajnim delom, posledica nedovoljne osposobljenosti ovog sektora preduzeća u domenu finansijskog upravljanja;

- velika mogućnost korupcije i

- višak zaposlenih i neadekvatna kvalifikaciona i starosna struktura zaposlenih.

Brojni problemi se javljaju u poslovanju javnih preduzeća na lokalnom nivou, a ogledaju se u: tehničkotehnološkoj zastarelosti, predimenzioniranosti mnogih od ovih preduzeća, sklonosti ka neracionalnoj potrošnji uz istovremeno postojanje visoke zaduženosti, gubitaka i visoke budžetske zavisnosti, te nesposobnosti da sopstvenim sredstvima finansiraju učešće u potrebnim investicijama većeg obima.
Od početka tranzicije $u$ Republici Srbiji nije bilo pokušaja da se sprovede istinski proces restrukturiranja javnih preduzeća. U periodu nakon 2000. godine, najveći deo promena je bio usmeren ka promeni organizacione strukture i smanjenju broja zaposlenih. I pored preduzetih mera javna preduzeća u Republici Srbiji još uvek ne daju rezultate srazmerne svom značaju, očekivanjima i velikom privrednom potencijalu.

Bitno je napomenuti da $\mathrm{u}$ stručnoj javnosti postoje i dalje oprečna mišljenja o privatizaciji, pri čemu se upravo ističe značaj procesa prestruktuiranja javnih preduzeća, koji prethodi privatizaciji. Tako se zaključuje da je, bez obzira na to da li će javna preduzeća biti privatizovana ili ne, neophodan nastavak restrukturiranja da bi se unapredila njihova efikasnost.

Dve osnovne grupe faktora koje utiču na proces restrukturiranja javnih preduzeća u Republici Srbiji mogu se podvesti pod eksterne i interne faktore (Mihajlović, Mihić i Rađenović, 2013, 157-176).

Eksterni faktori su u tesnoj vezi sa odgovarajućim institucionalnim ambijentom. Generator ovakvog ambijenta svakako je vlada jedne zemlje. Upravo institucionalni ambijent je najviše nedostajao tokom celog perioda tranzicije, kako bi generisao promene u poslovnom okruženju, jer preduzeća koja posluju u uslovima razvijenog tržišta osećaju unutrašnju potrebu, ali su i prinuđena da idu u različite aktivnosti restrukturiranja. To je neophodno kako bi obezbedili opstanak, rast i razvoj.

Interni faktori "guraju“ preduzeća da idu u promene i restrukturiranje. Interni faktori se ogledaju u pritisku vlasnika na menadžere da preduzeće kreira visok nivo blagostanja. Stiče se utisak da u javnim preduzećima u Republici Srbiji nije jasno definisano ko postavlja ciljeve, ko vodi preduzeće ka zacrtanim ciljevima, a ko sprovodi kontrolu.

Bez jasno definisanih vlasničkih odnosa nedostaje veoma bitan unutrašnji impuls za restrukturiranje javnih preduzeća da vrše promene kako bi se kreiralo i povećalo njihovo materijalno stanje. 
Situacija u kojoj se nalaze javna preduzeća nalaže hitno započinjanje procesa restrukturiranja koje ne može biti opšte i važiti jednako za sve. Ovaj proces mora da se kontinuirano sprovodi u svakom preduzeću, uzimajući u obzir njegove specifičnosti. Proces restruktuiranja će se razlikovati od preduzeća do preduzeća i u većini preduzeća podrazumeva smanjenje broja zaposlenih, ali i unapređenje upravljanja.

Unapređenje upravljanja javnim preduzećima treba da doprinese povećanju njihove efikasnosti putem smanjenja nepotrebnog trošenja resursa, povećanja obima i poboljšanja kvaliteta usluga, modernizaciju tehnologije i sl. Povećanje efikasnosti javnih preduzeća ima veliki značaj za ukupnu privredu i građane, kako zbog velike vrednosti usluga koje oni isporučuju, tako i zbog velikog dela društvenog bogatstva koje se nalazi pod njihovom kontrolom.

Značajan segment reforme javnog sektora Republike Srbije odnosi se i na reformu penzijskog sistema.

Javni penzijski sistem Republike Srbije se bazira na principu međugeneracijske solidarnosti - aktivni radnici plaćaju penzijske doprinose iz kojih se isplaćuju penzije trenutnih penzionera.

Penzijsko osiguranje je podeljeno $\mathrm{u}$ tri stuba:

- Prvi stub je obavezno državno penzijsko osiguranje. Ono funkcioniše po principu tekućeg finansiranja, gde se uplaćeni doprinosi u PIO fondu na teret poslodavca i zaposlenih, odmah isplaćuju u vidu penzija sadašnjim penzionerima.

- Drugi stub je obavezno dopunsko privatno penzijsko osiguranje u kome se deo obaveznih doprinosa koji bi išli u državni penzijski fond, usmerava u obavezan privatni penzijski fond, tako da zaposleni mogu ostvarivati pravo na dve penzije - privatnu i državnu.

- Treći stub je dobrovoljno penzijsko osiguranje koje daje mogućnost svima da, bez obzira da li su zaposleni ili ne, izdvoje dodatne penzijske doprinose na lične račune i u budućnosti obezbede dodatnu penziju.

Republički fond za penzijsko i invalidsko osiguranje osnovan je Zakonom o penzijskom i invalidskom osiguranju radi ostvarivanja prava iz penzijskog i invalidskog osiguranja i obezbeđivanja sredstava za ostvarivanje ovih prava (Raičević, 2008, 304). Fond je pravno lice sa statusom organizacije za obavezno socijalno osiguranje, sa pravima i obavezama utvrđenim Zakonom i Statutom. Fond obezbeđuje pravo na penzijsko i invalidsko osiguranje svim licima koja su po Zakonu obavezno osigurana i koja su se uključila u ovo osiguranje, bez obzira na to da li su u pitanju zaposleni, lica koja obavljaju samostalnu delatnost ili poljoprivrednici.

Suočavajući se sa novim strukturnim ekonomskosocijalnim i demografskim promenama: tendencija povećanja dužine životnog doba stanovništva, nezaposlenost, negativni efekti visokih doprinosa penzijskog osiguranja na isplaćene zarade zaposlenih, nosioci ekonomske politike veliko ograničenje imaju u povećanju javnih rashoda na ime isplata penzija. Naime, povećanje penzijskih rashoda postalo je glavni teret javnih finansija $\mathrm{u}$ Republici Srbiji poslednjih decenija. Zato povećanje penzijskih rashoda zahteva preduzimanje reformi penzijskog osiguranja u pravcu porasta stope doprinosa, izmene obračunskog perioda za utvrđivanje penzijskog osnova i mehanizma usklađivanja visine penzija, kao i smanjenja prava iz penzijskog osiguranja.

Javni rashodi za penzije počivaju na demografskim i makroekonomskim veličinama. Stopa rađanja, trajanje životnog doba i migracioni tokovi, makroekonomska kretanja, dinamika kretanja bruto domaćeg proizvoda, visina zarada, smanjenje stope zaposlenosti i socijalni faktori (prevremeno penzionisanje, zahtevi za invalidske penzije), najvažniji su elementi koji opredeljuju kretanje stanja sredstava penzijskog osiguranja. $\mathrm{Na}$ visinu javnih rashoda za penzije, svakako, utiče i promena zakonodavstva (mehanizam usklađivanja penzija sa tekućim ekonomskim prilikama ili mehanizam indeksacije, propisani uslovi za penzionisanje i dr.) (Hrustić i Dimitrijević, 2009, 89101).

Podaci u Tabeli 2 pokazuju kako se broj osiguranika prema broju korisnika penzije smanjivao iz godine u godinu. Ovo pokazuje koliko je realna mogućnost održivosti penzionog sistema ukoliko bi se nastavio 
ovaj trend povećavanja broja penzionera u odnosu na broj zaposlenih.

Tabela 2 Kretanje odnosa broja korisnika penzije i broja osiguranika iz kategorije zaposlenih u Republici Srbiji

\begin{tabular}{cccc}
\hline Godina & $\begin{array}{c}\text { Brojkorisnika } \\
\text { penzije }\end{array}$ & $\begin{array}{c}\text { Broj } \\
\text { osiguranika }\end{array}$ & Odnos \\
\hline & 1 & 2 & $1: 2$ \\
1999 & 1.263 .315 & 1.992 .181 & $1: 1,5$ \\
2000 & 1.264 .175 & 1.927 .588 & $1: 1,5$ \\
2001 & 1.297 .004 & 1.919 .255 & $1: 1,5$ \\
2002 & 1.255 .814 & 1.876 .390 & $1: 1,5$ \\
2003 & 1.248 .662 & 1.841 .219 & $1: 1,5$ \\
2004 & 1.241 .082 & 1.841 .656 & $1: 1,5$ \\
2005 & 1.239 .573 & 1.839 .461 & $1: 1,5$ \\
2006 & 1.267 .574 & 1.792 .497 & $1: 1,4$ \\
2007 & 1.290 .611 & 1.760 .437 & $1: 1,4$ \\
2008 & 1.306 .394 & 1.772 .418 & $1: 1,4$ \\
2009 & 1.324 .338 & 1.678 .760 & $1: 1,3$ \\
2010 & 1.345 .733 & 1.605 .052 & $1: 1,2$ \\
2011 & 1.357 .846 & 1.542 .282 & $1: 1,1$ \\
2012 & 1.420 .892 & 1.518 .792 & $1: 1,1$ \\
\hline
\end{tabular}

Izvor: Republički zavod za penzijsko i invalidsko osiguranje, 2012

Za optimalno funkcionisanje i likvidnost penzionog sistema je bolje da što više zaposlenih ide na jednog penzionera. Ovde je bitno napomenuti da na ovaj odnos znatno utiče i činjenica da u Republici Srbiji postoji tendencija starenja stanovništva, što povećava broj penzionera iz godine u godinu. Takođe, kako nezaposlenost raste iz godine $\mathrm{u}$ godinu, i veliki broj mladih ne može da nađe posao, utoliko će se ovaj odnos i dalje nepovoljno kretati, zbog smanjenja broja zaposlenih u odnosu na broj penzionera. Zato kažemo da je indirektan faktor koji može da utiče na poboljšanje ovog odnosa u budućnosti, otvaranje novih radnih mesta, i samim tim smanjivanje nezaposlenosti.
Međutim, još jedan faktor može da utiče na povoljnije kretanje ovog odnosa, a to je pomeranje naviše granice za odlazak u penziju.

Iako su u periodu od 2002. do 2010. godine, u više navrata sprovođene reforme penzijskog sistema, Republika Srbija i dalje spada u grupu zemalja sa problematičnom održivošću javnog penzijskog sistema. Rashodi za penzije čine 13\% BDP, što je za 4,5\% više od proseka u tranzicionim Evropskim državama i predstavlja teret koji privreda i poreski obveznici ne mogu dugoročno da izdrže.

Jedan od uzroka neodrživosti penzijskog sistema je činjenica da dosadašnje reformske mere nisu sankcionisale penzionisanje pre regularne starosne granice, tako da se oko 70\% muškaraca penzioniše pre 65 godine života, odnosno, oko $50 \%$ žena penzioniše se pre 60 godina starosti (Slika 4).

Poređenja radi, u zemljama Evropske unije postoji stalna tendencija pomeranja naviše granice za odlazak u penziju, pa tako u Velikoj Britaniji muškarci odlaze u penziju sa 65, žene sa 60 godina, u Portugaliji žene sa 62, muškarci sa 65 godina. U Grčkoj su standardne godine života za sticanje starosne penzije povećane na 65 godina starosti i za muškarace i žene.

Imajući u vidu prethodno navedenu analizu, kao imperativ se nameću sledeće mere reforme penzijskog sistema Republike Srbije:

- Uvođenje sistema aktuarskih faktora, odnosno, penala za prevremeno penzionisanje i nagrada za kasno penzionisanje. Ova mera bi omogućavala da penzijski sistem bude finansijski neutralan $\mathrm{u}$ odnosu na osiguranike (istih generacija) koji se penzionišu u različitim starosnim dobima. U praksi bi to značilo da osiguranici koji se prevremeno/kasno penzionišu dobijaju srazmerno umanjenu/uvećanu penziju, kako bi se ostvarila finansijska ekvivalencija između osiguranika koji se penzionišu u različitim starosnim dobima.

- Postepeno izjednačavanje starosne granice za odlazak u penziju za muškarce i žene do granice od 65 godina. Ova mera je već godinama predmet debate, ne samo u domaćoj već i stranoj literaturi. Ona praktično omogućava da se radni 


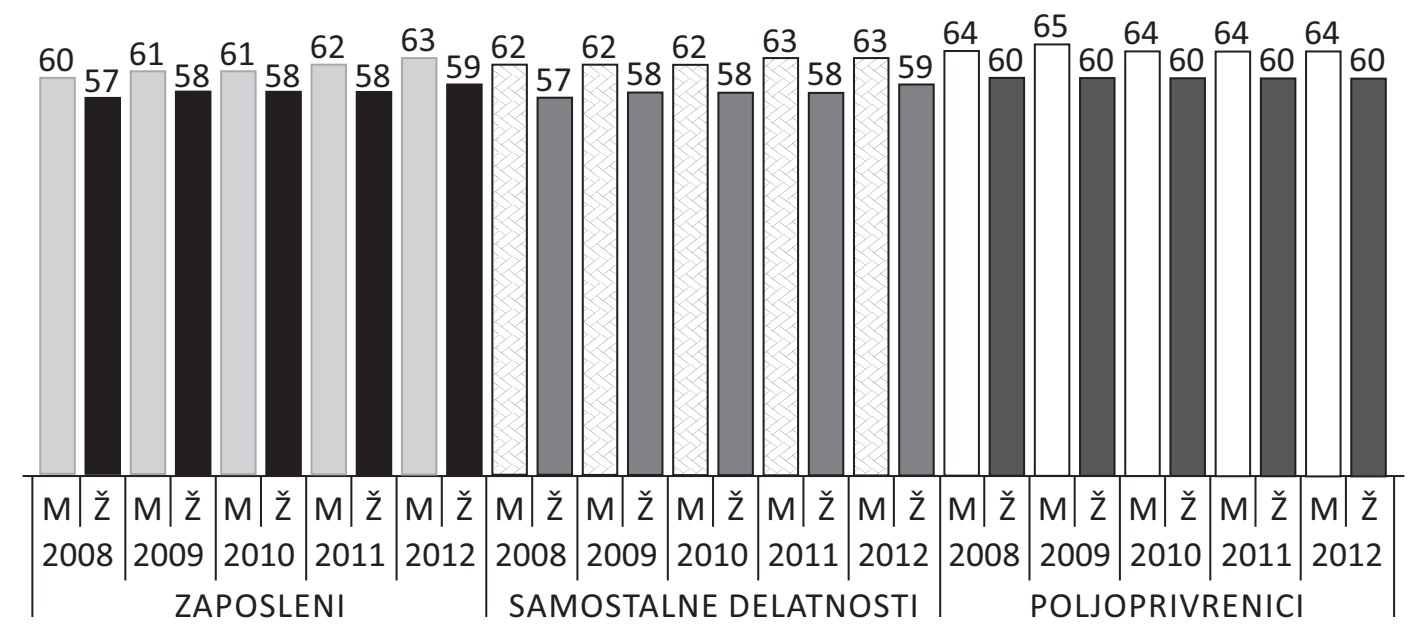

Slika 4 Prosečna starost korisnika penzija u Republici Srbiji u periodu 2008-2012

Izvor: Autor, na osnovu: Republički zavod za penzijsko i invalidsko osiguranje, 2012

staž zaposlenih produži, i time produži i period uplata doprinosa $\mathrm{u}$ fond penzijskog osiguranja. Ovde posebno treba uzeti $\mathrm{u}$ obzir faktor produžavanja životnog veka ljudi, koji dodatno utiče na podizanje ove starosne granice. Naime, kako se životni vek ljudi produžava, trebalo bi zajedno pomerati naviše i granicu za odlazak u penziju. Jer ukoliko do toga ne bi došlo, sve bi bio nepovoljniji odnos između broja zaposlenih i broja penzionera, a to bi negativno uticalo na likvidnist Fonda penzijskog osiguranja. Na Slici 5 prikazana je starosna granica za odlazak u penziju posle reformi sprovedenih 2012. godine.

- Povećanje starosne granice za odlazak u penziju za oba pola, u skladu sa produženjem očekivanog životnog veka populacije. Nosioci ekonomske politike u Republici Srbiji sve više najavljuju mogućnost da se i institucionalno (zakonski) pomeri starosna granica za odlazak u penziju na 65 godina života i za muškarce, i za žene. Međutim, kod primene ove mere se mora voditi računa jer ukoliko bi i nakon primene svih ovih mera i dalje postojao nesklad u finansijskoj ravnoteži, poslednji korak bi bilo razmatranje povećanja stope doprinosa. Ovo je najrigoroznija mera koja bi mogla nepovoljno da utiče na standard sada zaposlenih, ukoliko ne bi došlo do srazmernog povećanja njihovih zarada.

- Uvođenje smanjenja penzijskih nadoknada penzionisanim licima koja rade. Imajući u vidu rezultate dosadašnjih reformi sistema penzijskog osiguranja i neophodnost prilagođavanja demografskim promenama, dugogodišnji problem nelikvidnosti fonda penzijskog osiguranja trebalo bi rešavati većom dinamikom ekonomskih aktivnosti koje bi, pre svega, išle u pravcu rasta bruto domaćeg proizvoda i zaposlenosti. Osim toga, neophodno je izvršiti reforme samog penzijskog sistema, jer definisana davanja za penzije se odnose na paušalna davanja dela doprinosa, a ne na sadašnje vrednosti anuiteta (Clark, Sandler Morrill \& Vanderweide, 2014, 73).

U okviru reforme penzijskog osiguranja, potrebna je promena obračunskog perioda za utvrđivanje visine penzija, zatim, promena usklađivanja visine penzija, pooštravanje uslova za sticanje penzije, među kojima je najvažnije povećanje standardnih godina života za sticanje starosne penzije. $S$ druge strane, ne sme se izgubiti iz vida da je životni standard i nivo 


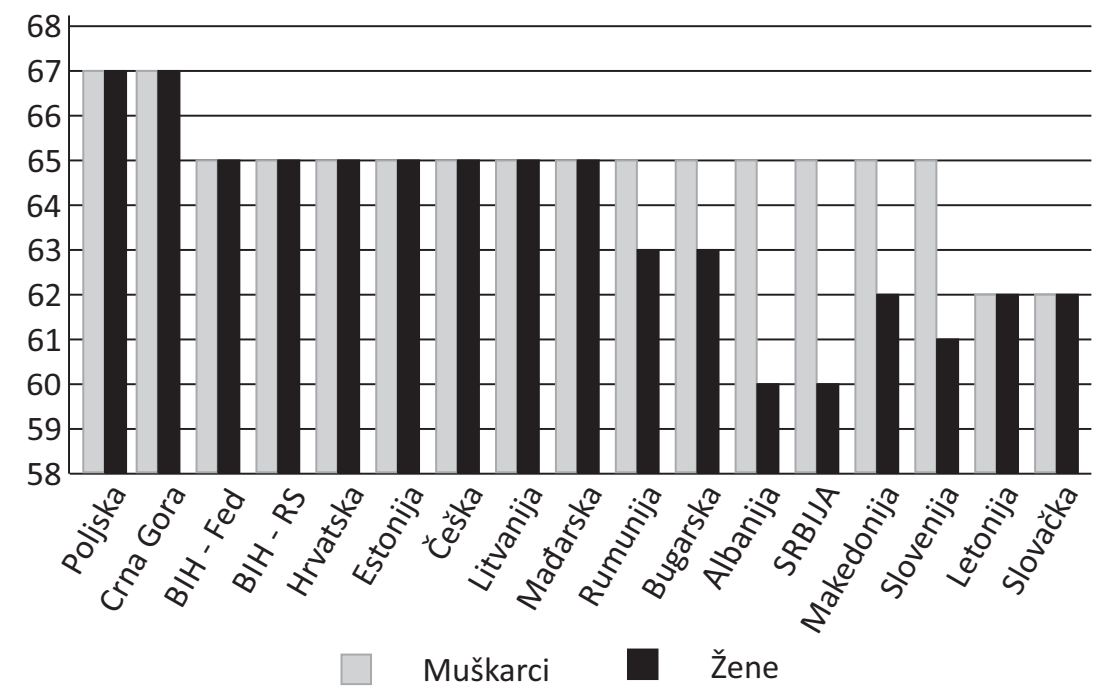

Slika 5 Prosečna starost korisnika penzija u Republici Srbiji i drugim zemljama, nakon reforme sprovedene 2012 Izvor: Altiparmakov, 2013, 45

kupovne snage penzionera i socijalna kategorija i da je manevarski prostor za dalje smanjivanje visine penzija izuzetno uzak gledajući dosadašnje ekonomske pokazatelje u celini. Pogotovo u uslovima globalne ekonomske krize, visina penzija je segment koji bi svakako trebalo zaštititi kroz mere za ublažavanje efekata krize.

Prioritet $\mathrm{u}$ rešavanju problema nelikvidnosti sistema penzijskog osiguranja u Republici Srbiji bi morao da bude stimulisanje ekonomskog oporavka i stvaranje uslova za privredni rast. U svakom slučaju, mere ekonomske politike treba da stimulišu povećanje proizvodnje i zaposlenosti, čime bi se povećao broj obveznika penzijskog osiguranja, a time i obim naplaćenih prihoda od doprinosa za penzijsko osiguranje.

Značajan segment reforme javnog sektora u Republici Srbiji odnosi se i na reformu sistema zdravstvene zaštite.

Poznato je da javni izdaci za zdravstvenu zaštitu u svetu predstavljaju jedan od najbrže rastućih elemenata javnih rashoda $\mathrm{u}$ proteklih nekoliko decenija. Empirijska istraživanja pokazuju da najveći uticaj na troškove za zdravstvenu zaštitu, $\mathrm{u}$ odnosu na bruto domaći proizvod, imaju tehnički progres u medicini, sve veća dostupnost zdravstvene zaštite velikom broju stanovnika i starenje populacije.

Javni izdaci za zdravstvo u Republici Srbiji, prema podacima Svetske zdravstvene organizacije, učestvuju sa oko $70 \%$ u ukupnim izdacima za zdravstvo (Arsić i drugi, 2010, 166). Ukoliko pogledamo Sliku 6, koja obuhvata podatke zaključno sa 2011. godinom, videćemo da je učešće ukupnih rashoda za zdravstvenu zaštitu u bruto domaćem proizvodu Republike Srbije poraslo za jedan procentni poen u 2008. u odnosu na prethodnu godinu i stabilizovalo se $u$ narednim godinama na $10,4 \%$, uz blagi porast u 2009 . godini na $10,5 \%$. Učešće privatnih rashoda za zdravstvenu zaštitu se, nakon povećanja od pola procentnog poena u 2008. godini, zadržalo na $4 \%$ bruto domaćeg proizvoda. Učešce rashoda za zdravstvenu zaštitu Republičkog fonda za zdravstveno osiguranje $u$ bruto domaćem proizvodu iznosilo je, u posmatranom periodu, 


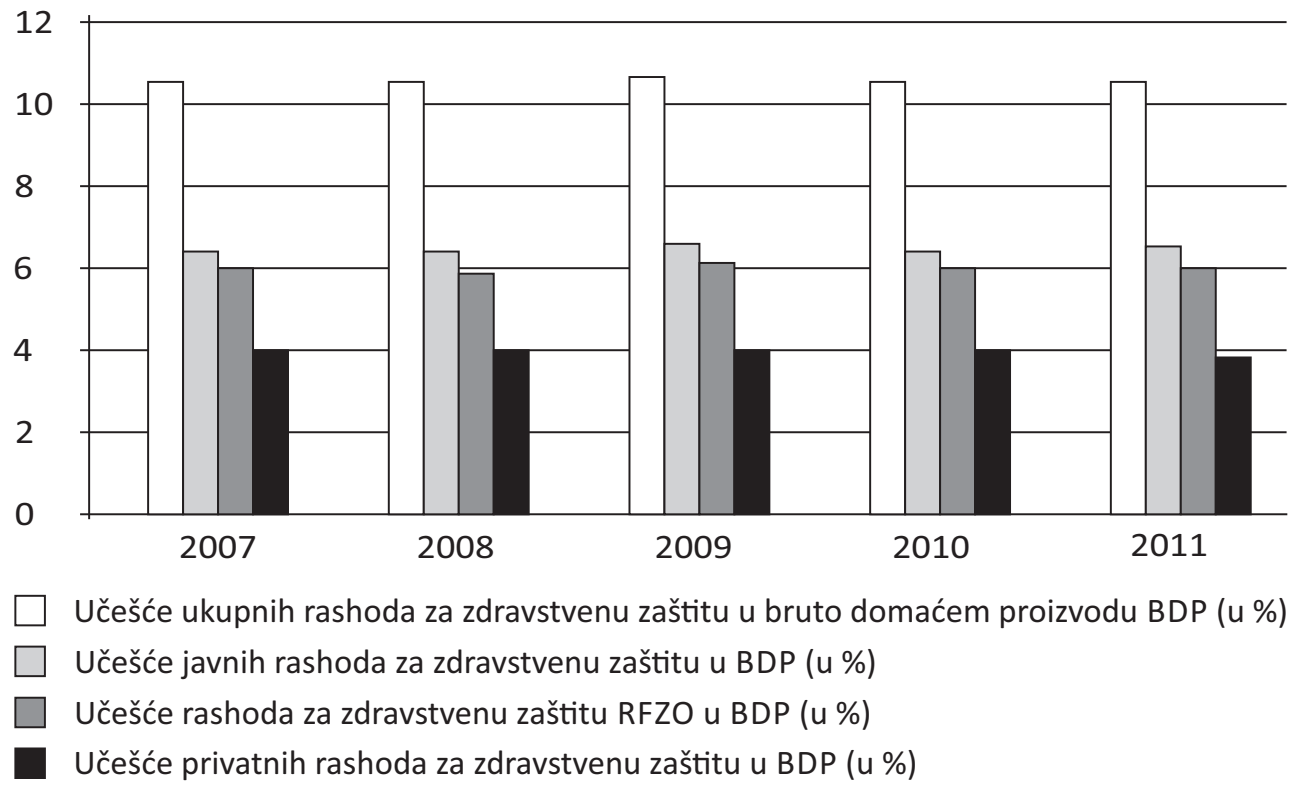

Slika 6 Učešće izvora finansiranja zdravstvene zaštite u BDP Republike Srbije

Izvor: Autor, na osnovu: Institut za javno zdravlje Srbije, 2011

približno $6 \%$, s tim što je u 2007. godini povećano za pola procentnog poena i blago osciliralo u naredne dve godine. Učešće javnih rashoda za zdravstvenu zaštitu u bruto domaćem proizvodu bilo je, u proseku, 6,4\% u čitavom posmatranom periodu.

Posmatrajući izdvajanja za zdravstvenu zaštitu kao procenat bruto domaćeg proizvoda, Republika Srbija je, sa svojih 10,4\%, približno na nivou Belgije, Austrije, Grčke i Bosne i Hercegovine, a znatno više od niza zemalja: Albanije, Bugarske, Hrvatske, Češke, Estonije, Finske, Mađarske, Letonije, Litvanije, Luksemburga, Crne Gore, Poljske, Rumunije, Rusije, Slovačke, Makedonije i Turske.

Međutim, Slika 7 pokazuje da, u poređenju sa zemljama Evropske unije i nekim drugim evropskim zemljama, Republika Srbija izdvaja u apsolutnom iznosu mala sredstva za zdravstvenu zaštitu, što je posledica relativno niskog nivoa bruto domaćeg proizvoda.
Imajući u vidu činjenicu da su javni izdaci za zdravstvenu zaštitu u Republici Srbiji, posmatrani u odnosu na bruto domaći proizvod, veći nego u sličnim zemljama u tranziciji, a da su rezultati zdravstvene zaštite na nivou proseka, može se reći da postoji značajna neefikasnost u zdravstvenom sistemu. To, svakako, nameće potrebu za temeljnom reformom zdravstvenog sistema, koja bi rezultirala poboljšanjem efikasnosti zdravstvene zaštite.

Prema preporuci Svetske banke, najvažnije uštede u javnom zdravstvenom sistemu Republike Srbije odnose se, pre svega, na smanjenje broja nemedicinskog osoblja u segmentima javnog zdravstva i na poboljšanje procedure odlučivanja o kupovini nove tehnologije i odobravanju novih lekova na tzv. pozitivnu listu. Takođe se, kao mogući pravac, navodi i informatizacija celokupnog sistema administracije usluga koje pružaju zdravstvene ustanove i uvođenje elektronskih knjižica. Naime, zbog toga što se istorije bolesti pacijenata vode i dalje na tradicionalan način, dolazi do neefikasnosti 


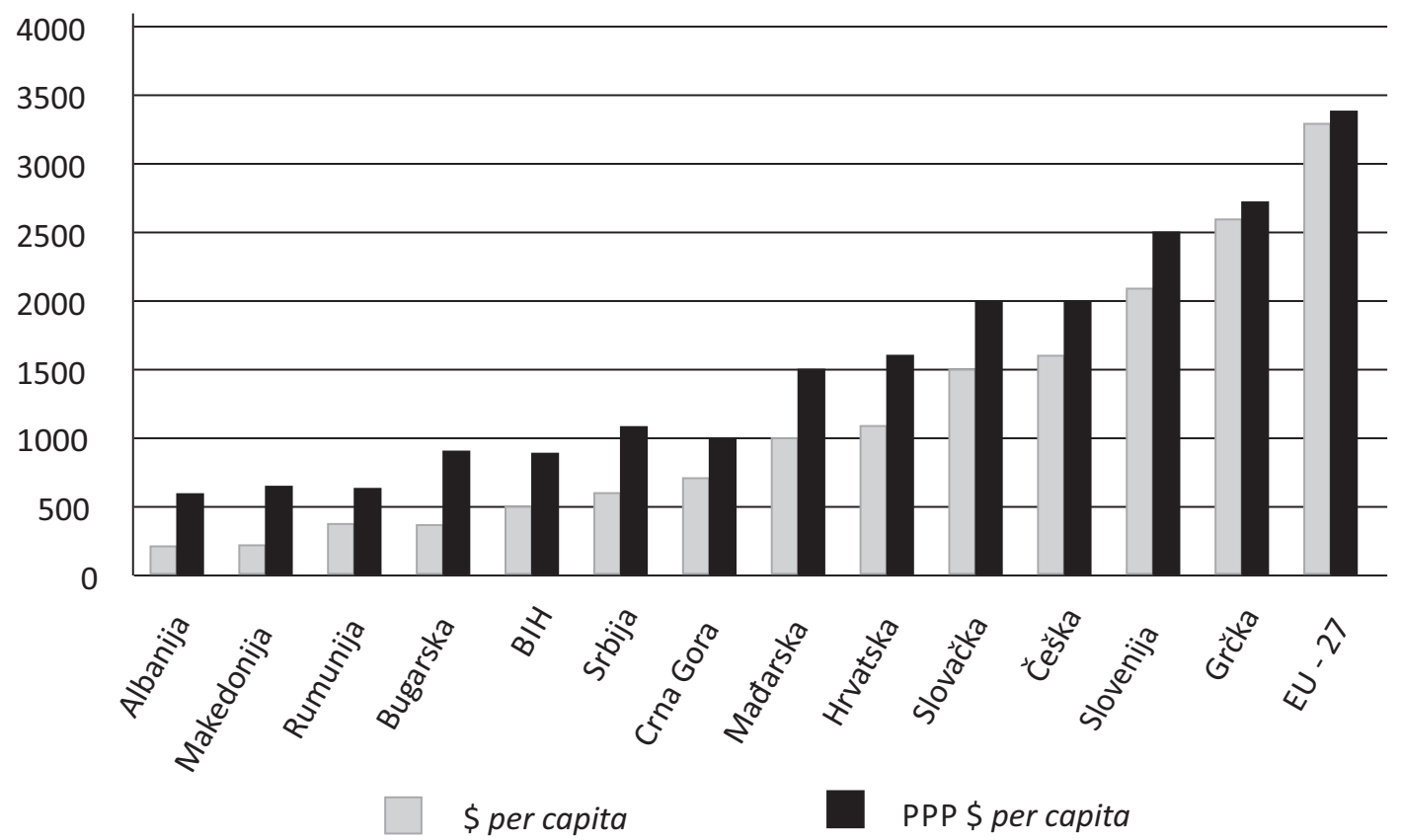

Slika 7 Ukupni rashodi za zdravstvenu zaštitu (u dolarima po stanovniku i u dolarima po kupovnoj moći po stanovniku) u Republici Srbiji, EU-27 i izabranim evropskim zemljama

Izvor: Autor, na osnovu: Institut za javno zdravlje Srbije, 2012

funkcionisanja celokupnog sistema, koji je zatrpan ogromnim brojem kartona, pri čemu se često podaci o pacijentima gube. Elektronska baza podataka bi pomogla da se ovi problemi suzbiju, i omogućila bi lakši i brži pristup informacijama o pacijentima.

Realizacija ovih reformi zahteva visoku opreznost kako se ne bi ponovile greške iz prošlosti. Smanjivanje broja zaposlenih u zdravstvu, koje se zasnivalo na dobrovoljnom odlasku zaposlenih, uz relativno visoke otpremnine, rezultiralo je time da su zdravstveni sistem napustili neki od najpotrebnijih medicinskih kadrova i prešli u privatni sektor. Pri tom je nemedicinsko osoblje, u kojem postoje viškovi, ostalo nepromenjeno, što je ugrozilo funkcionalnost zdravstvenog sistema.

Racionalizacija broja zaposlenih u zdravstvenom sistemu Republike Srbije mora da uvaži postojanje značajne neravnomernosti $u$ produktivnosti zdravstvenih ustanova. Naime, više od polovine domova zdravlja ima iskorišćenost kapaciteta manje od dve trećine dok, s druge strane, postoje i domovi zdravlja koji su preopterećeni. Ovakva iskorišćenost kapaciteta u domovima zdravlja je delimično posledica činjenice da se demografska slika Republike Srbije, sa teritorijalnog aspekta, značajno izmenila u poslednjih dvadesetak godina.

Prema preporuci Svetske banke, povećanju efikanosti zdravstvenih ustanova, mogla bi da doprinese i promena načina finansiranja javnog zdravstvenog sistema u Republici Srbiji. Naime, sadašnji zdravstveni sistem se finansira na troškovnom principu, tj. zdravstvene ustanove dobijaju sredstva od Fonda zdravstvenog osiguranja $u$ zavisnosti od broja i strukture zaposlenih, troškova lekova i broja postelja. Ključni refomski koraci u ovom sektoru podrazumevaće sasvim drugačiji model finansiranja, tako što će se zdravstvena zaštita finansirati po korisniku zdravstvene usluge. Primenom ovog modela, 
domovi zdravlja koji imaju veći broj pacijenata dobijali bi više sredstava. Uštede $u$ zdravstvenom sistemu koje bi se ostvarile primenom ovih mera, iskoristile bi se za kupovinu savremene medicinske opreme, poboljšanje stručne osposobljenosti medicinskog osoblja i rekonstrukciju zdravstvenih ustanova. Osim toga, značajna sredstva bi mogla biti preusmerena $u$ sistem socijalne zaštite.

U Republici Srbiji postoji preko dvadeset programa socijalne pomoći. Ciljevi ovih programa mogu se svrstati u tri grupe:

- smanjenje siromaštva,

- rast stanovništva, $\mathrm{i}$

- pomoć ugroženim grupacijama (borci i invalidi).

Prema zvaničnim podacima, rashodi za socijalnu zaštitu u Republici Srbiji su znatno niži od većine drugih zemalja u tranziciji. Ukupni rashodi za socijalnu zaštitu su ispod $2 \%$ bruto domaćeg proizvoda, dok su ovi rashodi u zemljama Centralne Evrope $u$ intervalu od 3 do 4\%. Ipak, ukoliko bismo uključili razne oblike državne pomoći, stvarni izdaci za socijalnu zaštitu u Republici Srbiji su verovatno nešto veći, jer se u Republici Srbiji i dalje određene socijalne funkcije na različite načine prenose na preduzeća, pa siromašniji slojevi stanovništva dobijaju popuste pri plaćanju komunalnih usluga i slično (Arsić i drugi, 2010, 172).

Još jedna nepovoljna okolnost $\mathrm{u}$ sistemu socijalne zaštite je ta što je relativno mali deo programa socijalne pomoći direktno usmeren ka rešavanju problema siromaštva. Relativno skromna sredstva koja su u Republici Srbiji namenjena siromašnima su nedovoljna. Stoga je u okviru programa socijalne zaštite neophodno povećati sredstva koja su direktno namenjena rešavanju ovog problema. Da bi ova sredstva došla do onih kojima su potrebna, neophodno je otkloniti administrativne barijere, poput zahteva za prijavu mesta boravka, izdavanje ličnih dokumenata i dr. Među siromašnim licima koja imaju pravo na socijalnu pomoć postoji značajan broj onih koji su nepismeni i koji nisu upoznati sa programima socijalne pomoći. Stoga je neophodno da službe socijalne pomoći aktivno pomažu takvim licima u ostvarivanju prava na socijalnu zaštitu.
Reforma socijalne zaštite u Republici Srbiji bi trebalo da obuhvati i preformulisanje socijalne politike tako da bude pravična i racionalna. Pravična socijalna politika sadrži programe koji su okrenuti najsiromašnijima. $S$ druge strane, oni treba da budu u potpunosti uključeni $\mathrm{u}$ te programe. Na primer, socijalnim programom tzv. trinaeste penzije obuhvaćeni su samo siromašni penzioneri. Međutim, oni čine svega $25 \%$ od ukupnog broja siromašnih u Republici Srbiji. Racionalna socijalna politika vodi računa o tome da izdvajanja ne ugroze stabilnost budžeta. Na primer, u Republici Srbiji se oko trećine budžetskih sredstava izdvaja za penzije i socijalnu pomoć, što u srednjem roku nije održivo. Stoga je potrebno postojeća sredstva racionalnije koristiti (Fiskalni savet Republike Srbije, 2012, 12).

Tokom narednih godina neophodno je izraditi socijalne karte kako bi se utvrdilo ko su najsiromašniji slojevi građana, i tako se omogućilo da socijalni programi budu fokusirani na njih. Fiskalna konsolidacija realizovana putem povećanja poreza, na jednoj, i realno smanjenje plata i penzija, na drugoj strani, imaće za rezultat privremeno dodatno pogoršanje standarda građana. Socijalni pritisak će biti veliki, a natprosečan teret konsolidacije podneli bi zaposleni $\mathrm{u}$ javnom sektoru, što je sa ekonomskog stanovišta opravdano, jer su plate $\mathrm{u}$ javnom sektoru veće nego $\mathrm{u}$ privatnom, a rizik od gubitka posla manji. Izradom socijalnih karata pomoglo bi se da socijalna pomoć dođe do korisnika kojima je ona stvarno potrebna a, s druge strane, došlo bi do racionalizacije broja korisnika.

Bilo bi poželjno da se $\mathrm{u}$ socijalno zbrinjavanje siromašnih uključe i lokalne samouprave, koje, nakon izmena Zakona o finansiranju lokalne samouprave, raspolažu sa više sredstava, čiji bi deo mogle da koriste za programe socijalne zaštite. Lokalne zajednice bi mogle socijalnom zaštitom da obuhvate i one građane koji su u teškom materijalnom položaju, a ne primaju pomoć iz budžeta Republike Srbije. Međutim, i u ovom slučaju neophodne su selektivnost i targetiranost, kako bi ograničena finansijska sredstva došla do onih kojima su najpotrebnija. Stoga bi prednost trebalo dati merama koje su usmerene na pomoć porodicama $\mathrm{u}$ stanju krajnjeg siromaštva, umesto merama koje nisu uslovljene ekonomskim stanjem korisnika. 


\section{ZAKLJUČAK}

Više od jedne decenije nakon otpočinjanja procesa tranzicije u Republici Srbiji, nakon inicijalnog uspeha, veliki napredak je izostao. Republika Srbija, prema tranzicionim indikatorima Evropske banke za obnovu i razvoj i indikatorima međunarodne konkurentnosti Svetskog ekonomskog foruma, zaostaje za uspešnim tranzicionim zemljama i svoj privredni rast je zasnivala više na rastu domaće potrošnje i uvoza, zahvaljujući prihodima od privatizacije i zaduživanjem $\mathrm{u}$ inostranstvu, nego na reformama i konkurentnosti (Maksimović, 2012). Prema procenama, Republika Srbija je dostigla nivo koji su uspešne zemlje ostvarile devedesetih godina prošlog veka, sa stanovišta privrednog ambijenta, sprovedenih reformi i evropskih integracionih procesa.

Republika Srbija, kao i druge zemlje Zapadnog Balkana, zaostaje u tranziciji i zbog toga treba da ubrza reformske procese. Bez ubrzanih reformi nije moguće povećati kredibilitet zemlje i smanjiti rizike ulaganja. U tom kontekstu je od posebnog značaja reforma javnog sektora, privatizacija javnih preduzeća, razvijanje javno-privatnog partnerstva, smanjivanje sive ekonomije i korupcije.

U procesu pridruživanja Evropskoj uniji, pred Republikom Srbijom su postavljeni veoma kompleksni zahtevi, čije je ispunjavanje jedan od osnovnih uslova za dalji napredak u procesu integracije. Svakako, poseban akcenat je stavljen na reformu javnog sektora.

Promene u javnom sektoru imaju svoj institucionalni, ekonomski, ali i socijalni aspekt. Koliko su promene $\mathrm{u}$ javnom sektoru specifične, pokazuju primeri zemalja $\mathrm{u}$ okruženju, u kojima građani burno reaguju na podizanje starosne granice za odlazak u penziju, smanjenje zaposlenosti u javnim preduzećima, privatizaciju javnih preduzeća. Naime, reforme javnog sektora, obuhvatajući racionalizaciju samog sektora, reformu penzijskog sistema, socijalne i zdravstvene zaštite, tangiraju sve nas i naš životni standard. Zato je bitno da se ove promene sprovode postepeno, kako ne bi dovele do socijalnih nemira.

Često se reforma javnog sektora karakteriše kao najbolnija u procesu tranzicije i to se mora uzeti u obzir od strane nosilaca ekonomske politike. Ta reforma ima i značajan kvalitativni aspekt. Kvalitet javnog sektora u Republici Srbiji, posebno poslednjih godina, dobija sve više na značaju paralelno sa potrebom za modernizacijom javnih službi i usvojenim ciljevima reforme javne uprave. Uvođenje ekonomskih načela $u$ procenu rada javnih službi i sve veća usmerenost na zahteve korisnika približavaju još više javni sektor načinima poslovanja biznis sektora. Pored fokusiranja na zahteve korisnika, postavlja se kao značajan i kriterijum neophodnosti primene kontinuiranih unapređenja unutar javnog sektora što, takođe, nosioci ekonomske politike moraju imati u vidu.

$\mathrm{U}$ ovom radu jasno su istaknute osnovne smernice $\mathrm{u}$ kom pravcu treba razvijati javni sektor čime je, $\mathrm{u}$ najvećoj meri, potvrđena hipoteza da je za uspešan završetak procesa tranzicije privrede Republike Srbije, neophodno sprovođenje sveobuhvatne reforme njenog javnog sektora. Naravno, brojna otvorena pitanja koja se, pre svega, tiču modela i oblika finansiranja javnog sektora, ostaju i dalje predmet interesovanja ekonomske nauke i struke.

\section{ZAHVALNICA}

Ovaj rad je deo Projekta osnovnih istraživanja (br. 179015), koji finansira Ministarstvo prosvete, nauke i tehnološkog razvoja Republike Srbije.

\section{REFERENCE}

Altiparmakov, N., (2013). Unapređenje intergeneracijske pravičnosti i održivosti penzijskog sistema Srbije. Ekonomske ideje i praksa, 4(11), 31-54.

Anđelić, G., i Đaković, V. (2013). Reforma javnog sektora Republike Srbije - pravci, trendovi i izazovi. Poslovna ekonomija, 7(1), 59-78.

Arsić, M. i drugi (2010). Reforma javnog sektora. U Postkrizni model ekonomskog rasta i razvoja Srbije 2011-2020. Beograd, Srbija: Fond za razvoj ekonomske nauke, Ekonomski fakultet Univerziteta u Beogradu

Clark, R. L., Sandler Morrill, M., \& Vanderweide, D. (2014). Defined benefit pension plan distribution decisions by 
public sector employees, Journal of Public Economics, 116(1), 73-88.

Dimitrijević, M., i Cvetković, Z. (2010). Reforma javnog sektora u Republici Srbiji po modelu javno-privatnog partnerstva. Anali medunarodne konferencije mladih lidera,1(1), 121-130.

Đuričin, S. (2011). Tranzicija i kretanje zaposlenosti u javnom i privatnom sektoru, U J. Zubović (Ur.), Aktione mere na tržištu rada i pitanje zaposlenosti (str. 298-318). Beograd, Srbija: Institut ekonomskih nauka.

Eurostat. (2012). Employment statistics, http://epp.eurostat. ec.europa.eu/statistics_explained/index.php/Employment_ statistics

Fiskalni savet Republike Srbije. (2012). Mišljenje na predlog Fiskalne strategije za 2013. sa projekcijama za 2014. i 2015.godinu. Beograd, Srbija: Fiskalni savet Republike Srbije.

Hrustić, H., i Dimitrijević, M. (2009). Stanje i perspektive penzijskog osiguranja u Srbiji. Socijalna misao, 16(4), 89-102.

IMF (n.d.) Preuzeto 05.06.2014. sa http://www.imf.org/external/ pubs/cat/longres.aspx?sk=40778.0. Republic of Serbia 2013 Article IV Consultation, Country Report No.13/206.

IMF (n.d.) Preuzeto 06.06.2014. sa http://elibrary-data.imf. org/FindDataReports.aspx?d=33061\&e=170809 Government Finance Statistics (GFS) - eLibrary Data,

Institut za javno zdravlje Srbije. (2011). Svrsishodnost i potreba razvoja sistema NZR, Analiza kretanja rashoda za zdravstvenu zaštitu. www.batut.org.rs

Institut za javno zdravlje Srbije. (2012). Odabrani zdravstveni pokazatelji za 2011. godinu. www.batut.org.rs.

Krstić, B., Stevanović, T., i Džunić, M. (2011). Određeni aspekti merenja performansi u organizacijama javnog sektora. Ekonomske teme, 49(3), 433-448.

Maksimović, Lj. (2012). Sistemska ograničenja konkurentnosti privrede Srbije. Ekonomski horizonti, 14(2), 99-109. doi:10.5937/ ekonhor1202099M

Mihajlović, M., Mihić, S., i Rađenović, D. (2013). Restruktuiranje javnih preduzeća u Srbiji - usmeravanje ka tržišnim principima poslovanja. Poslovna ekonomija, 7(1), 157-176.

Ministarstvo finansija Republike Srbije. (2011). Analiza poslovanja javnih preduzeća u 2010. godini. Beograd.

Ministarstvo finansija Republike Srbije. (2013a). Informacija o paketu mera za stabilizaciju javnih finansija $i$ oporavak privrede. Beograd.

Ministarstvo finansija Republike Srbije. (2013b). Bilten javnih finansija. Beograd, 17(decembar), 4-38.

Petrović, P. (2009). Efekat svetske finansijske krize na Srbiju i odgovor ekonomske politike. Ekonomika preduzeća, 57(1-2), 43-50.

Raičević, B. (2008). Javne finansije. Beograd, Srbija: Ekonomski fakultet Univerziteta u Beogradu.

Republički fond za penzijsko i invalidsko osiguranje. (2012). Statistički godišnji bilten. www.pio.rs/cir/

Republički zavod za statistiku. (2013). Anketa o radnoj snazi. http://webrzs.stat.gov.rs/WebSite/

Veselinović, P. (2007). Stanje reformi i prioriteti ekonomske politike Srbije. Ekonomski horizonti, 9(1/2), 53-72.

Zakon o jaonim preduzećima, Službeni glasnik Republike Srbije, br. 119/2012, br. 116/2013, br. 44/2014 - dr.zakon.

Primljeno 13. juna 2014, nakon dve revizije, prihvaćeno za publikovanje 19. avgusta 2014.

Petar Veselinović je vanredni profesor na Ekonomskom fakultetu Univerziteta u Kragujevcu, gde je doktorirao iz uže naučne oblasti Opšta ekonomija i privredni razvoj. Oblasti njegovog naučnog istraživanja su ekonomski sistem, makroekonomske politike, regionalni razvoj. Autor je i koautor šest univerzitetskih udžbenika i monografija i 130 naučnih radova publikovanih u međunarodnim i nacionalnim naučnim časopisima i saopštenim na konferencijama. 


\title{
THE REFORM OF THE PUBLIC SECTOR AS THE KEY DETERMINANT OF THE TRANSITION ECONOMY OF THE REPUBLIC OF SERBIA
}

\author{
Petar Veselinovic \\ Faculty of Economics, University of Kragujevac, Kragujevac, Serbia
}

The economy of the Republic of Serbia is at an important turning point now. The first phase of the implementation of the transition process is completed, the reform processes are gaining a new momentum and entering the European Union is becoming more certain. In order to successfully finalize the transition processes,the reform of the public sector's system of functioning is inevitable, among other reforms. The public sector in Serbia is low-productive and inefficient, irrationally set, with a multitude of problems that for many years have constantly been growing and becoming more complicated. The high rate of employment and average salaries in the public sector, on the one hand, and the poorly-formulated operational systems, on the other, are so designed that the public sector has a bad influence on economic development in general. The paper will analyze the situation in the public sector of the Republic of Serbia, with a special emphasis on creating a realistic basis for its reform, as a key determinant of the successful completion of the transition process, taking into account the specifics of the Republic of Serbia's economy.

Keywords: transition, reform of the public sector, business environment, pension system, social protection

JEL Classification: $\mathrm{H} 10, \mathrm{H} 55, \mathrm{H} 60$ 